\title{
Contribution of atmospheric processes affecting the dynamics of air pollution in South-Western Europe during a typical summertime photochemical episode
}

\author{
M. Gonçalves ${ }^{1}$, P. Jiménez-Guerrero ${ }^{2}$, and J. M. Baldasano ${ }^{1,2}$ \\ ${ }^{1}$ Projects Engineering Department, Technical University of Catalonia, Barcelona, Spain \\ ${ }^{2}$ Barcelona Supercomputing Center-Centro Nacional de Supercomputación, Barcelona, Spain
}

Received: 15 July 2008 - Published in Atmos. Chem. Phys. Discuss.: 23 October 2008

Revised: 5 January 2009 - Accepted: 6 January 2009 - Published: 3 February 2009

\begin{abstract}
The southern Mediterranean region frequently experiences critical levels of photochemical pollutants during summertime. In order to account for the contribution of different atmospheric processes during this type of episodes, the WRF-ARW/HERMES/CMAQ modelling system was applied with high resolution $\left(1 \mathrm{~km}^{2}, 33\right.$ sigma vertical layers, $1 \mathrm{~h}$ ) to assess the different dynamics in a coastal environment and an inland-continental zone: the North-Eastern and Central Iberian Peninsula (NEIP and CIP, respectively). The former is characterized by a very complex terrain, while the latter behaves as a flat area, which clearly affects the pattern of local flows. A representative type of photochemical pollution episode (occurring over $78 \%$ of summer days) which occurred during 17-18 June, 2004 is selected as the study period. The CMAQ Integrated Process Rate provides the hourly contributions of atmospheric processes to net $\mathrm{O}_{3}, \mathrm{NO}_{\mathrm{x}}$ and NMVOCs concentrations. The $\mathrm{O}_{3}$ photochemical formation occurs mainly in downwind areas from the main $\mathrm{NO}_{\mathrm{x}}$ emission sources during midday. At surface level it accounts for 50 to $75 \mu \mathrm{g} \mathrm{m}^{-3} \mathrm{~h}^{-1}$. The urban areas and main roads, as main sources of $\mathrm{NO}_{\mathrm{x}}$ emissions, act as $\mathrm{O}_{3}$ sinks, quenching up to $-200 \mu \mathrm{g} \mathrm{m}^{-3}$ per hour during the traffic circulation peaks. The $\mathrm{O}_{3}$ concentration gradient generated, larger during daytime, increases the contribution of diffusion processes to ground-level $\mathrm{O}_{3}$ (up to $200 \mu \mathrm{g} \mathrm{m}^{-3} \mathrm{~h}^{-1}$ fluxes, mainly from upper vertical layers). The maximum positive contributions of gas-phase chemistry to $\mathrm{O}_{3}$ occur in the coastal domain at high levels (around 500 to $1500 \mathrm{~m}$ a.g.l.), while in the continental domain they take place in the whole atmospheric
\end{abstract}

Correspondence to:

P. Jimenez-Guerrero

(pedro.jimenez@bsc.es) column under the PBL. The transport of ozone precursors by advective flows determines the location of the maximum $\mathrm{O}_{3}$ surface concentrations. The $\mathrm{O}_{3}$ chemical formation involves the oxidation of less NMVOCs in the NEIP than in the CIP domains, due to differences in chemical sensitivity between these areas. The dry deposition is an important sink in the lowest layer of the model, together with vertical diffusion flows. Finally, the contributions from cloud processes, wet deposition and heterogeneous chemistry are negligible during the whole episode, characterized by a high solar radiation and neither precipitation nor cloudiness. This process analysis provides new quantitative information about the origin of the peaks of $\mathrm{O}_{3}$ and its precursors, aiding the design of abatement strategies in South-Western Europe.

\section{Introduction}

Atmospheric chemistry transport model simulations suggest that summertime $\mathrm{O}_{3}$ is enhanced in the entire Mediterranean troposphere, contributing substantially to the radiative forcing of climate and air quality issues (Lawrence et al., 1999; Hauglustaine and Brasseur, 2001; Jiménez et al., 2006). Specifically the South-Western Europe and the Iberian Peninsula (IP) frequently experience photochemical pollution episodes during summertime, in which $\mathrm{O}_{3}$ and $\mathrm{PM}_{10}$ exceedances of the European air quality targets are registered (EC, 2008).

Atmospheric modelling is a fundamental tool to assess the processes contributing to air quality levels in these situations. Nevertheless, the air quality models usually provide the net concentration of pollutants, without the capabilities of understanding and isolating the atmospheric processes involved,

Published by Copernicus Publications on behalf of the European Geosciences Union. 
Table 1. Summary of the WRF-ARW meteorological model configuration.

\begin{tabular}{ll}
\hline Domains definition & Physical parameterizations \\
\hline Four one way nested domains & ARW dynamical core \\
D1-European domain $55 \times 55$ cells of $54 \mathrm{~km}$ & Yonsei University PBL scheme \\
D2-Iberian Peninsula domain $94 \times 82$ cells of $18 \mathrm{~km}$ & Kain-Fritsch (D1-D2) and explicit (D3-D4) cumulus scheme \\
D3- Iberian Peninsula Zone: $104 \times 103$ cells of $6 \mathrm{~km}$ & Single Moment 3 class microphysics' scheme \\
D4a- North-Eastern IP domain $322 \times 259$ cells of $1 \mathrm{~km}$ & RRTM for long-wave radiation \\
D4b- Central IP domain $181 \times 214$ cells of $1 \mathrm{~km}$ & scheme and Dudhia for short-wave scheme \\
(Schematic representation in Fig. 1$)$ & Noah Land Surface Model.
\end{tabular}

which would explain the reasons for a model's predictions and show the relative importance of each process (Jeffries and Tonnesen, 1994; Jang et al., 1995a, b). For the Mediterranean area, these issues have been studied by measurement campaigns, but also combining both modelling and experimental techniques (e.g. Millán et al., 1996; 1997; Lelieveld et al., 2002; Lawrence et al., 2003; Roelofs et al., 2003; Cros et al., 2004; Dufour et al., 2005; Jonson et al., 2006; among others). Currently, some Eulerian grid models, such as the Models-3 Community Multiscale Air Quality Model CMAQ (Gipson, 1999), permits to assess the contribution of different atmospheric processes to the net concentrations of pollutants.

This analysis is useful not only for a better understanding of the atmospheric behaviour of an specific area, i.e. New York (Jang et al., 1995a, b) or the Puget Sound Region USA (Jiang et al., 2002); but also for assessing which are the models or the models' configurations presenting better skills (Jeffries and Tonnesen, 1994; O’Neil and Lamb, 2005). The peer-reviewed works applying the process analysis focus mainly on episodic events (San José et al., 2002; O'Neil and Lamb, 2005), although annual (Zhang et al., 2006) and even climatologic simulations (Hogrefe et al., 2005) have been also performed.

This work aims to assess and quantify the contribution of different atmospheric processes to the concentration of $\mathrm{O}_{3}$ and its precursors in South-Western Europe by means of the Integrated Process Rate (IPR) analysis tool available in the CMAQv4.6 model. In order to highlight the different behaviour of atmospheric dynamics in a coastal environment and an inland-continental zone, the North-Eastern and Central Iberian Peninsula domains (NEIP and CIP, respectively) have been selected. These areas show different topographic patterns, the former being a coastal region characterized by a very complex terrain and the latter a continental inner region with a much simpler topography, which brings different locally-driven flows. They house the largest Spanish urban centres, Barcelona and Madrid, and therefore photochemical pollution episodes are of special concern by their direct effects on population. In addition the urban pollution plume effects can spread hundred of km away from the cities affecting not only human health, but also damaging crops and agricultural activities developed in those areas.

\section{Methods}

\subsection{Modeling system}

The WRF-ARW/HERMES-2004/CMAQ modelling system is applied with high spatial $\left(1 \mathrm{~km}^{2}\right)$ and temporal resolution $(1 \mathrm{~h})$ to the study areas. The fine scale used is essential in complex terrains such as those studied (Jiménez et al., 2005, 2006).

The Weather Research and Forecasting (WRF) Model (Michalakes et al., 2004; Skamarock et al., 2005) provides the meteorology parameters as inputs to CMAQ. The initial and boundary conditions are obtained from the National Centers for Environmental Prediction (NCEP) reanalysis data (available at the standard pressure levels for every $6 \mathrm{~h}$ with $0.5 \times 0.5$ degree resolution). Four nested domains are defined over each study area (Table 1 ), covering the final domains (D4; Fig. 1): the NEIP $\left(322 \times 259 \mathrm{~km}^{2}\right)$ and the CIP $\left(181 \times 214 \mathrm{~km}^{2}\right)$, respectively. 33 sigma vertical layers cover the troposphere (up to $50 \mathrm{hPa} \approx 20 \mathrm{~km}$ ), with 12 layers under the PBL.

The High Elective Resolution Emission Modelling System (HERMES) has been developed for Spain with a high spatial $\left(1 \mathrm{~km}^{2}\right)$ and temporal $(1 \mathrm{~h})$ resolution (Baldasano et al., 2008). This model focuses on the estimation of gas and particulate matter pollutants, including the ozone precursors. HERMES considers the emissions from the following sources: (1) power generation plants, (2) industrial installations, (3) domestic and commercial fossil fuel use, (4) domestic and commercial solvents use, (5) road transport, (6) ports, (7) airports and (8) biogenic emissions; using a bottom-up approach except for the domestic and commercial fossil fuel use, where a top-down approach was adopted and regional emissions were allocated to fine grid cells by surrogate indexes. It follows the methodologies and criteria of previous emission models developed for the Eastern Iberian 

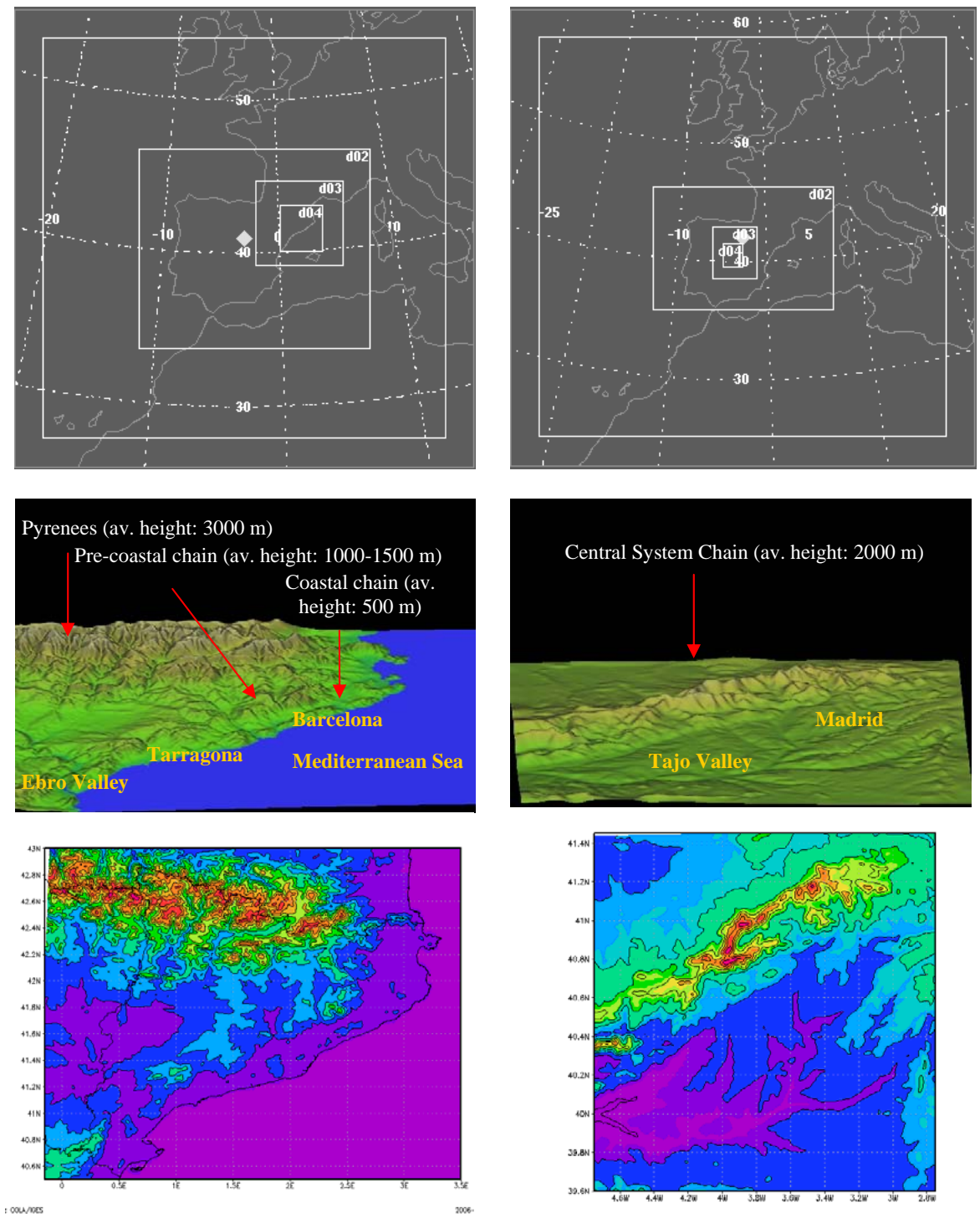

Fig. 1. Selected domains and topography of the final study areas (D4): North-Eastern IP- $322 \times 259 \mathrm{~km}^{2}-($ left $)$ and Central IP-181 $\times 214 \mathrm{~km}{ }^{2}$ - (right) domains.

Peninsula: EMICAT2000 (Parra et al., 2004, 2006) and EMIVAL (Arévalo et al., 2004). The reference year chosen is 2004 , since it is the most recent year in which all the needed data for the HERMES development are available. HERMES generates results according to the European Environmental Agency's Selected Nomenclature for Air Pollution (SNAP). Furthermore, HERMES has the capacity of presenting results according to individual installations, industrial activities, land use classification or type of pollutant or process (fugitive, evaporative, hot or cold emissions).

The chemistry transport model used to compute the concentrations of photochemical pollutants is CMAQ (Byun and Schere, 2006). The initial and boundary conditions were derived from a one-way nested simulation covering a domain of $1392 \times 1104 \mathrm{~km}^{2}$ centred in the Iberian Peninsula, that used EMEP emissions for 2004, disaggregated to $18 \mathrm{~km}$. A 48-h spin-up was performed to minimize the effects of initial conditions for the final domains. The chemical mechanism selected for the simulations following the criteria of Jiménez et al. (2003) was Carbon Bond IV (CBM-IV) (Gery et al., 1989) including aerosols and heterogeneous chemistry. The CMAQ model configuration uses the Yamartino-Blackman Cubic scheme (YAM) for the advection and convection transport and the Eddy diffusion scheme for the vertical and horizontal diffusion. $\mathrm{NO}_{\mathrm{x}}$ and volatile organic compounds (VOC) speciation of HERMES emissions are detailed in Parra et al. (2006). The vertical and horizontal resolution of the final domains (D4; Fig. 1) are the same as those used in the meteorological simulation $\left(1 \mathrm{~km}^{2}, 33\right.$ vertical layers $)$ and the species concentration and atmospheric processes contributions are estimated hourly. 
The high resolution employed and the huge number of variables involved in the atmospheric integrations (not only the pollutants concentrations, but also the process analysis) require high-performance computing. The availability of the MareNostrum supercomputer hold in the BSC-CNS, together with the advances in the parallelization of air quality codes, has allowed these simulations.

\subsection{Integrated process rate (IPR)}

The contributions of different processes are assessed by means of the Integrated Process Rate (IPR) analysis available in the CMAQv4.6 model. It provides the effects of all the physical processes and the net effect of chemistry on model predictions, which is the fraction of the mass or concentration in each model cell (or group of cells) in terms of the process that gave rise to this portion of the mass or concentration. More details can be found in Jeffries and Tonnesen (1994); Jang et al. (1995a, b) and Gipson (1999). The contributions are estimated for each cell $\left(1 \mathrm{~km}^{2}\right)$ on a hourly basis, providing the gas-phase chemistry, the net transport (horizontal and vertical advection), horizontal and vertical diffusion, emissions, dry and wet deposition and clouds interactions contributions to the net concentration of pollutants. The main assumptions of the modelling system are summarized below in order to clarify the subsequent discussion of results (Gipson, 1999):

(1) Net transport: it considers the sum of horizontal and vertical advection, which is the transport of pollutants due to the mean wind fields. The advection scheme used is globally mass-conserving. The horizontal advection is estimated by the piecewise parabolic method (PPM) (Colella and Woodward, 1984) scheme, deriving a vertical velocity component at each grid cell that satisfies the mass continuity equation using the driving meteorology model's air density. The vertical advection module works with no mass-exchange boundary conditions at the bottom or top of the model. In this work the net effect of horizontal and vertical advection is considered to obtain comparable contributions with the rest of the processes. As already pointed out by Jiang et al. (2003), in some cases it could be more meaningful to aggregate the contributions of several processes instead of considering each of them separately.

(2) Gas phase chemistry: CBM-IV mechanism is used with the Euler Backward Iterative (Hertel et al., 1993) solver.

(3) Diffusion: the diffusion involves sub-grid scale turbulent mixing of pollutants. Horizontal diffusion is estimated by a diffusion coefficient based on local wind deformation. Vertical diffusion is estimated using the Eddy diffusivity theory.

(4) Dry deposition: the deposition process is simulated as a flux boundary condition that affects the concentration in the lowest layer.
(5) Clouds chemistry and wet deposition: clouds play a key role in aqueous chemical reactions, vertical mixing of pollutants and removal of pollutants by wet deposition. They also indirectly affect the concentration of pollutants by altering the solar radiation, which, in turn, affects photochemical pollutants, such as ozone, and the flux of biogenic emissions. CMAQ models sub-grid convective precipitating clouds, sub-grid non-precipitating clouds, and grid-resolved clouds. The cloud module vertically redistributes pollutants for the sub-grid clouds, calculates in-cloud and precipitation scavenging, performs aqueous chemistry, and accumulates wet deposition amounts. The used scheme is a RADM based cloud processor that uses the asymmetric convective model to compute convective mixing.

(6) Aerosols: the third generation aerosol module takes chemical species concentrations and reactivity rates from the chemistry solvers and primary particulate concentrations from the emissions processor to compute fine and coarse particulate concentrations. The primary aerosols emissions are estimated by HERMES, not taking into account marine aerosols. The deposition velocity for particles is estimated from the aerosol size distribution, which is calculated from the mass and number concentration for each of the modes considered: Aitken $(0-0.1 \mu \mathrm{m})$, accumulation $(0.1-2.5 \mu \mathrm{m})$, and coarse $(2.5-10 \mu \mathrm{m})$

The contribution of processes in this work is analyzed in several ways:

(1) Analysis focused on model evaluation. The contribution of processes to the concentration of gaseous pollutants in the lowest vertical level is assessed for specific points in the domains, coincident with the location of characteristic air quality stations (AQS): rural background AQS and urban background AQS. The contributions are obtained as concentration $\left(\mu \mathrm{g} \mathrm{m}^{-3}\right)$ variation for the surface cell. The weighted contributions are also obtained taking into account the Eq. (1), where: $\% \mathrm{PC}_{i}$ is the relative contribution of the $i$ process to the net fluxes from or to the specific cell or domain (including chemical contributions) and $\mathrm{PC}_{j}$ is the contribution of each process, being $j=$ gas-phase chemistry, transport (horizontal plus vertical advection), emissions, horizontal and vertical diffusion, dry deposition, clouds processes and aerosols processes.

$\% \mathrm{PC}_{i}=\frac{\mathrm{PC}_{i}}{\sum_{j} \mathrm{abs}\left(\mathrm{PC}_{j}\right)} \cdot 100$

Note that the sum of $\% \mathrm{PC}_{i}$ for all $\mathrm{i}$ is not $100 \%$, but the sum of $\operatorname{abs}\left(\% \mathrm{PC}_{i}\right)$ is exactly $100 \%$.

(2) Analysis of the dynamics of pollutants during the episode. The processes are analyzed for the selected domains and up to the selected top of the atmosphere (33 sigma vertical layers up to $50 \mathrm{hPa}$ ) depicting contribution maps.

(3) Analysis of specific locations with high $\mathrm{O}_{3}$ levels during the episode. Finally, the contribution of the different processes is assessed for four selected subdomains 
$\left(20 \times 10 \mathrm{~km}^{2}\right)$ in which maximum $\mathrm{O}_{3}$ concentrations occur during the episode. Positive and negative contributions expressed as pollutants density under the PBL (height obtained from the model) in $\mathrm{g} \mathrm{m}^{-2}$ are assessed for $\mathrm{O}_{3}, \mathrm{NO}_{\mathrm{x}}$ and NMVOCs in each subdomain.

\subsection{Domains description}

The coastal domain (NEIP) covers $83398 \mathrm{~km}^{2}$ and is located in the Mediterranean littoral (Fig. 1-left). It is characterized by a very complex terrain, dominated in the northern part by the Pyrenees mountains (up to $3400 \mathrm{~m}$ ), and with two mountain chains parallel to the coast: the Pre-coastal (1000$1500 \mathrm{~m}$ height) and Coastal chains (500 m average height). The Ebro valley is located in the Southern region and acts as an important channel for local wind flows. The Central Plateau covers the inland area. The major sources of pollutants emission are the urban areas of Barcelona, accounting for 3.1 million inhabitants, and Tarragona, which is located in a densely industrialized area; and the road network connecting the Iberian Peninsula with France, all of them located along the coastal axis. Also inland some industrial areas have an important contribution to pollutants emissions (i.e. the Cercs power plant). The HERMES model estimates $299 \mathrm{t} \mathrm{d}^{-1}$ of $\mathrm{NO}_{\mathrm{x}}$ emitted during the episode, being $57 \%$ produced by on-road traffic, which constitutes the main source of primary pollutants in the region (Costa and Baldasano, 1996; Parra et al., 2006; Baldasano et al., 2008), contributing also $24 \%$ of the $692 \mathrm{td}^{-1}$ of NMVOCs emitted in the coastal domain. In this particular case $48 \%$ comes from biogenic sources. The industrial and power generation sectors are the main emitters of $\mathrm{SO}_{2}$ and primary particles, accounting for $94 \%$ and $71 \%$ of the mass emissions $\left(125 \mathrm{td}^{-1}, 45 \mathrm{td}^{-1}\right)$, respectively.

The continental (CIP) domain covers an area of $38734 \mathrm{~km}^{2}$ in the centre of the Iberian Peninsula (Fig. 1right). The main topographic features in the region are the Central System located in the north-western area of the domain, with summits reaching $2500 \mathrm{~m}$, and the Tajo valley in the southern area. Both clearly affect the wind flows during the episode, characterized by the dominance of mesoscale phenomena. The main emission sources in the region are the Madrid urban area, the Spanish administrative capital, which accounts for 5.8 million inhabitants; the road network that connects Madrid with surrounding conurbations and several industrial sources, mainly located in the south-western part of the domain. The HERMES emissions model indicates that on-road traffic accounts for $75 \%$ of total $\mathrm{NO}_{\mathrm{x}}$ emissions within the region $\left(231 \mathrm{td}^{-1}\right)$, and $19 \%$ of NMVOCs ( $790 \mathrm{t} \mathrm{d}^{-1}$ in the whole area), being the biogenic sources the main contributors to these primary pollutants $(64 \%)$. Industrial and power generation emissions of $\mathrm{SO}_{2}$ and primary particulate matter account for $90 \%$ and $65 \%$ of the total emissions ( $66 \mathrm{t} \mathrm{d}^{-1}$ and $36 \mathrm{t} \mathrm{d}^{-1}$, respectively).
Table 2. Summary of validation results for the hourly concentrations of pollutants during 17-18 June, 2004.

\begin{tabular}{|c|c|c|c|c|c|}
\hline $\begin{array}{l}45 \text { air } \\
\text { quality } \\
\text { stations } \\
\text { (AQS) data }\end{array}$ & $\begin{array}{r}\text { Bias } \\
\left(\mu \mathrm{g} \mathrm{m}^{-3}\right)\end{array}$ & $\begin{array}{r}\text { Error } \\
\left(\mu \mathrm{g} \mathrm{m}^{-3}\right)\end{array}$ & $\begin{array}{r}\text { MNBE } \\
(\%)\end{array}$ & $\begin{array}{r}\text { MNGE } \\
(\%)\end{array}$ & $\begin{array}{r}\text { UPA } \\
(\%)\end{array}$ \\
\hline $\mathrm{O}_{3}$ & 4.9 & 25.6 & $7.95 \%$ & $25.89 \%$ & $-0.39 \%$ \\
\hline $\mathrm{NO}_{2}$ & -16.0 & 27.0 & $-12.68 \%$ & $50.92 \%$ & $-28.35 \%$ \\
\hline $\mathrm{SO}_{2}$ & -8.9 & 11.0 & $-35.76 \%$ & $47.95 \%$ & $-35.33 \%$ \\
\hline $\mathrm{PM}_{10}$ & -12.1 & 16.9 & $-15.86 \%$ & $38.59 \%$ & $-48.42 \%$ \\
\hline $\begin{array}{l}\text { Coastal } \\
\text { Domain } \\
(\mathrm{NEIP}) \\
(33 \mathrm{AQS})\end{array}$ & $\begin{array}{r}\text { Bias } \\
\left(\mu \mathrm{g} \mathrm{m}^{-3}\right)\end{array}$ & $\begin{array}{r}\text { Error } \\
\left(\mu \mathrm{g} \mathrm{m}^{-3}\right)\end{array}$ & $\begin{array}{r}\text { MNBE } \\
(\%)\end{array}$ & $\begin{array}{r}\text { MNGE } \\
(\%)\end{array}$ & $\begin{array}{r}\text { UPA } \\
(\%)\end{array}$ \\
\hline $\mathrm{O}_{3}$ & 2.3 & 25.7 & $5.85 \%$ & $26.65 \%$ & $-5.18 \%$ \\
\hline $\mathrm{NO}_{2}$ & -26.7 & 34.5 & $-27.12 \%$ & $51.82 \%$ & $-31.87 \%$ \\
\hline $\mathrm{SO}_{2}$ & -10.0 & 12.9 & $-32.77 \%$ & $49.95 \%$ & $-29.23 \%$ \\
\hline $\mathrm{PM}_{10}$ & -3.3 & 16.1 & $15.19 \%$ & $50.65 \%$ & $-14.82 \%$ \\
\hline $\begin{array}{l}\text { Central } \\
\text { Domain } \\
(\mathrm{CIP}) \\
(12 \mathrm{AQS})\end{array}$ & $\begin{array}{r}\text { Bias } \\
\left(\mu \mathrm{g} \mathrm{m}^{-3}\right)\end{array}$ & $\begin{array}{r}\text { Error } \\
\left(\mu \mathrm{g} \mathrm{m}^{-3}\right)\end{array}$ & $\begin{array}{r}\text { MNBE } \\
(\%)\end{array}$ & $\begin{array}{r}\text { MNGE } \\
(\%)\end{array}$ & $\begin{array}{r}\text { UPA } \\
(\%)\end{array}$ \\
\hline $\mathrm{O}_{3}$ & 11.1 & 25.4 & $12.98 \%$ & $24.06 \%$ & $11.02 \%$ \\
\hline $\mathrm{NO}_{2}$ & -2.2 & 17.3 & $5.89 \%$ & $49.78 \%$ & $-23.83 \%$ \\
\hline $\mathrm{SO}_{2}$ & -6.8 & 7.1 & $-41.73 \%$ & $43.94 \%$ & $-47.53 \%$ \\
\hline $\mathrm{PM}_{10}$ & -14.4 & 17.1 & $-23.62 \%$ & $35.57 \%$ & $-56.82 \%$ \\
\hline
\end{tabular}

\subsection{Episode selection}

The 17-18 June, 2004 episode is characterized by a western recirculation in the synoptic scale, a typical summertime situation in South-Western Europe since these conditions dominate $45 \%$ of the annual and $78 \%$ of the summertime transport patterns over the coastal Mediterranean areas (Jorba et al., 2004 ) and $36 \%$ of the annual and $45 \%$ of the summertime situations in the central-continental areas of the Iberian Peninsula. They are frequently associated with local-to-regional episodes of air pollution related to high levels of $\mathrm{O}_{3}$ during summer (e.g. Toll and Baldasano, 2000; Barros et al., 2003; Ortega et al., 2004; Taghavi et al., 2004; Cousin et al., 2005; Coll et al., 2005; Jiménez et al., 2006; among others), being the study case one of the most polluted episodes of 2004 in the considered areas. The weak synoptic forcing and the stagnant conditions dominate the Iberian Peninsula. Therefore the mesoscale phenomena induced by the particular topography of the regions control the superficial wind flows. In these conditions the sea breezes and mountain-valley winds, and the development of the Iberian thermal low are characteristic features of the region (Jorba et al., 2004). The main processes inland are the convective circulations developed by the surface heating and the formation of compensatory subsiding flows in coastal areas (Millán et al., 1997; Pérez et al., 2004). 


\section{Results and discussion}

3.1 Summary of the model evaluation for the 17-18 June, 2004 episode

The surface concentrations of pollutants predicted by the WRF-ARW/HERMES/CMAQ model are evaluated against hourly data from 45 AQS (provided by the Environmental Departments of the Catalonia and Madrid Governments, Spain). The evaluation results for $\mathrm{O}_{3}$ accomplish the recommendations of the European Union, set by the European Directives 1999/30/EC and 2002/3/EC (uncertainty of 50\% for the air quality objective for modelling assessment methods). The US Environmental Protection Agency guidelines (US-EPA, 1991, 2007) recommend the use of different statistical parameters and combination of methods to assess a model performance, among them the mean normalized bias error (MNBE), the unpaired peak prediction accuracy (UPA) and the mean normalized gross error (MNGE). In the case of study the averaged MNBE for $\mathrm{O}_{3}$ is $7.95 \%$; the MNGE, $25.89 \%$ and the UPA, $-0.39 \%$ (Table 2). Moreover, the modelled $\mathrm{NO}_{2}, \mathrm{SO}_{2}$ and $\mathrm{PM}_{10}$ surface levels agree with observations, with values for these statistical parameters lower or around 50\%. The largest deviations are observed in the $\mathrm{NO}_{2}$ predictions accounting for $50.92 \%$ MNGE, nevertheless the reliability of the modelling system is acceptable being MNBE and the UPA $-12.68 \%$ and $-28.35 \%$, respectively; and the average absolute error and the mean bias accounting for $27 \mu \mathrm{g} \mathrm{m}^{-3}$ and $-16 \mu \mathrm{g} \mathrm{m}^{-3}$, respectively.

The $\mathrm{O}_{3}$ concentrations are overpredicted by the model both in the NEIP and CIP domains (Table 2), being the average normalized bias $5.85 \%$ in the former and $12.98 \%$ in the latter. Previous studies (Jiménez et al., 2006; JiménezGuerrero et al., 2008) point that under low pressure gradient situations mesoscale models tend to underestimate daytime wind flows in coastal areas, which would favour the $\mathrm{O}_{3}$ accumulation. The $\mathrm{O}_{3}$ peaks are overestimated in the CIP (UPA: $11.02 \%$ ), while an underprediction is assessed for the NEIP domain (UPA: $-5.18 \%$ ). The flow patterns in both domains differ, presenting the NEIP a very complex behaviour, with layering of pollutants and multiday accumulations that may be not accurately reproduced by the model, causing this underprediction in peak concentrations.

$\mathrm{NO}_{2}$ concentrations are overpredicted in the CIP domain (positive bias of 5.89\%), which could be attributed to the weaknesses of the model to represent wind flows under this low pressure gradient situation. The uncertainties related to the emissions account and the atmospheric chemistry representation in the CMAQ model could also play an important role. The underprediction in the coastal domain (MNBE: $-27.12 \%$ ) could be related with inaccuracies in the modelled chemical behaviour, linked to $\mathrm{O}_{3}$ chemistry that may be causing also the high levels estimated for this pollutant. The $\mathrm{NO}_{2}$ peak concentrations are underestimated in both domains (UPA: $-26.3 \%$ in the CIP domain and $-23.73 \%$ in the
NEIP domain). Jiménez-Guerrero et al. (2008) run the WRFARW/HERMES/CMAQ model for the NEIP indicating an underprediction of $\mathrm{NO}_{2}$ due to the relatively low vertical resolution in the lower troposphere that could generate an artificial vertical exchange between the boundary layer and the free troposphere, enhancing the $\mathrm{NO}_{\mathrm{x}}$ venting. In this case, doubling the vertical resolution (33 vertical layers versus 16 in the mentioned study) leads to the same problem. This fact suggests that discrepancies between modelled and measured levels do not only depend on transport patterns, but also on the chemical behaviour represented by the model and on the emissions estimates.

The underestimation in $\mathrm{SO}_{2}$ concentrations in both domains (MNBE of $-32.77 \%$ and $-41.73 \%$ in the NEIP and CIP domains, respectively) and in peak levels (UPA of $-29.23 \%$ and $-47.53 \%$ ) could reflect a slight underestimation on sulphur oxides emissions.

On average, the $\mathrm{PM}_{10}$ concentrations are also slightly underpredicted (MNGE of $-15.86 \%$ and UPA $-48.42 \%$ ), which could be related not only to the inaccuracies in representing accumulation and transport patterns during this low gradient pressure situation, but also to the limitations related to the emissions model (HERMES) that does not take into account natural sources of primary particulates such as erosive or saltation processes or marine aerosols (Vautard et al., 2005).

The contribution of processes in the first simulated layer (0-38 m a.g.l.) provides useful information about the performance of the model for predicting surface $\mathrm{O}_{3}$ concentrations. The surface $\mathrm{O}_{3}$ concentration in rural background stations of the coastal domain (such as Agullana, Ponts and Rubí) and the continental domain (i.e. SM Valdeiglesias, Guadarrama and Buitrago de Lozoya) is overestimated during the morning and underestimated in the afternoon (the average bias is negative for the costal domain stations, $-8.1 \%,-7.1 \%$ and $-11.8 \%$, respectively, and $-8.01 \%, 10.27 \%$ and $2.21 \%$ for the continental domain AQS aforementioned). The representative sites selected reflect a common behaviour (see Fig. 2) independently of their location, which may indicate slight deviations in modelled advection fluxes. The vertical diffusion accounts for $33 \%$ of the net processes contribution to the surface cells, but is compensated by $32 \%$ removal of dry deposition. The processes controlling the total change in these cells' concentration are the net transport term (horizontal + vertical advection, accounting on average for $8 \%$ ) and chemical production (7\%). If the vertical transport (diffusion + dry deposition) is considered as a whole, the transport weight in the change of concentration involves $48 \%$ and chemistry $37 \%$ of positive contribution. The largest deviations in model predictions on the coastal domain stations occur specifically in the 16:00 to 20:00 UTC period, when the daytime breezes decrease and the land breezes and nighttime winds start developing. The surface winds during this period are overestimated by the meteorological model which in turn favours pollutants venting in the chemistry transport 

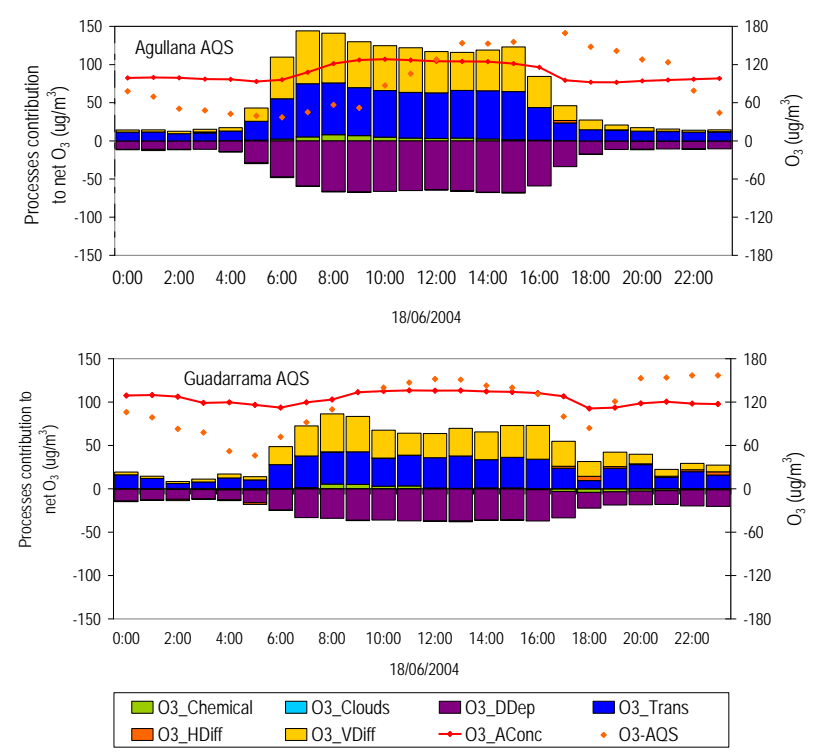

Fig. 2. Atmospheric processes contribution to net $\mathrm{O}_{3}$ concentration in the 1 st simulated vertical layer $\left(0-38 \mathrm{~m}\right.$ a.g.1.), $\mathrm{O}_{3}$ hourly average concentration and $\mathrm{O}_{3}$ measured in rural background air quality stations of the NEIP (up-Agullana AQS) and the CIP domain (down-Guadarrama AQS) during the 18 June, 2004.

model simulation. In the CIP concentrations are underestimated from 10:00 UTC, but maximum deviations are found in the 19:00-22:00 UTC period.

Previous works confirm the trend of the mesoscale meteorological models, and specifically the WRF-ARW, to underpredict the land breezes and underestimate the advective flows in the latter hours of the day (Jiménez-Guerrero et al., 2008), which causes overprediction in $\mathrm{O}_{3}$ concentrations during night-time. The average processes contributions to net $\mathrm{O}_{3}$ concentrations assessed during this period indicates that net transport accounts for $56 \%$ and chemical destruction for $-26 \%$, when considering the combined effect of vertical processes (vertical diffusion + dry deposition).

In the locations of urban background stations (such as Barcelona-Ciutadella and Tarragona in the NEIP, or Aranjuez and Chapineria in the CIP) the modelled $\mathrm{O}_{3}$ has a similar behaviour (Fig. 3). Albeit during the morning there is an overestimation trend, during the afternoon and night-time the model predictions are frequently below the measured levels. The chemical regime in the NEIP domain involves $\mathrm{O}_{3}$ photochemical destruction in the first layer accounting for $-46 \%$ of net night-time fluxes and $-44 \%$ of net daytime fluxes on average, when considering the vertical fluxes as a whole (being the sum of vertical diffusion and dry deposition a positive term that accounts for $10 \%$ and $13 \%$, respectively). In the CIP the periods of $\mathrm{O}_{3}$ net formation occur in the first vertical layer during daytime, not existing in the urban background stations of the NEIP. On average the net effect of daytime gas
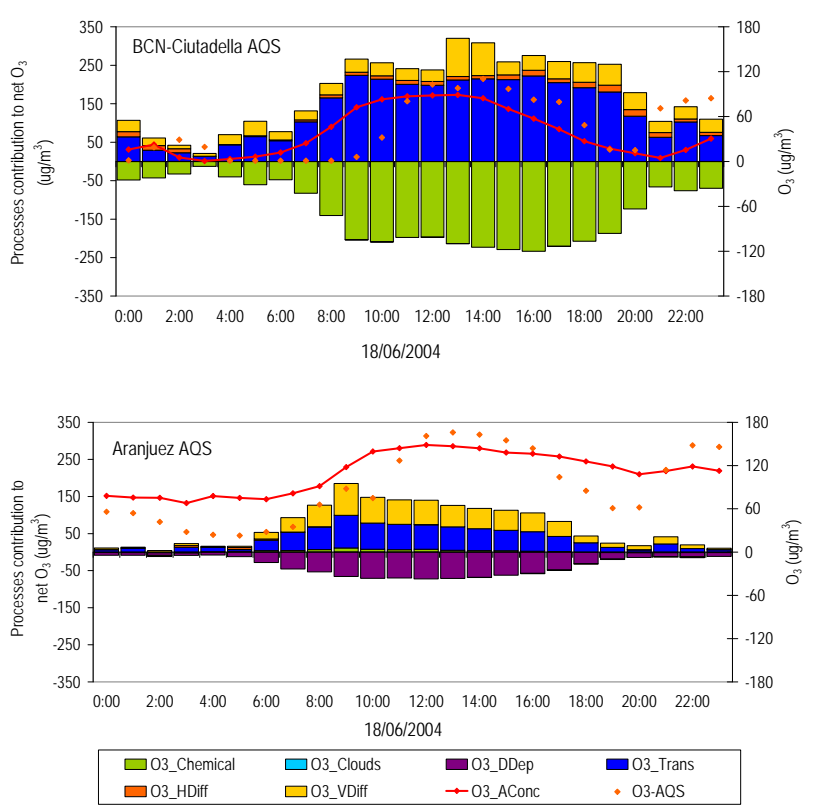

Fig. 3. Atmospheric processes contribution to net $\mathrm{O}_{3}$ concentration in the first simulated vertical layer (0-38 $\mathrm{m}$ a.g.1.), $\mathrm{O}_{3}$ hourly average concentration and $\mathrm{O}_{3}$ measured in urban background air quality stations of the NEIP (BCN-Ciutadella AQS) and the CIP domain (down-Aranjuez AQS) during the 18 June, 2004.

phase chemistry accounts for $-5 \%$ of total fluxes of $\mathrm{O}_{3}$. The main positive contributions come from net transport, involving $86 \%$ of net concentration variation in the surface cells. During night-time main sinks of $\mathrm{O}_{3}$ are chemical destruction $(-27 \%)$ and the vertical flux term (vertical diffusion plus dry deposition, that combined remove $-12 \%$ of net $\mathrm{O}_{3}$ fluxes). In the coastal domain stations the chemical destruction of $\mathrm{O}_{3}$ is the main removal process even during daytime, probably due to the $\mathrm{O}_{3}$ titration by $\mathrm{NO}_{\mathrm{x}}$ emissions. On-road traffic plays an important role in this sense being the major $\mathrm{NO}_{\mathrm{x}}$ emitter the Barcelona city area.

This behaviour is also reproduced by the model in urban stations such as Barcelona-Eixample, Constantí or L'Hospitalet (NEIP) and Majadahonda, Coslada or Leganés (CIP) where main contributions to surface $\mathrm{O}_{3}$ come from transport and vertical diffusion, and the main sinks are gasphase chemistry and dry deposition.

3.2 Dynamics of pollutants in the coastal and central southwestern Mediterranean

The results of the photochemical simulations for the coastal and central-continental domains show the maximum $\mathrm{O}_{3}$ concentrations occurring in downwind areas from Barcelona (NEIP) and Madrid (CIP) conurbations after the maximum photochemical activity hours (Fig. 4). During the day the increase of the solar radiation and the temperature (reaching $30-35^{\circ} \mathrm{C}$ in both domains) promote the high levels of $\mathrm{O}_{3}$, 


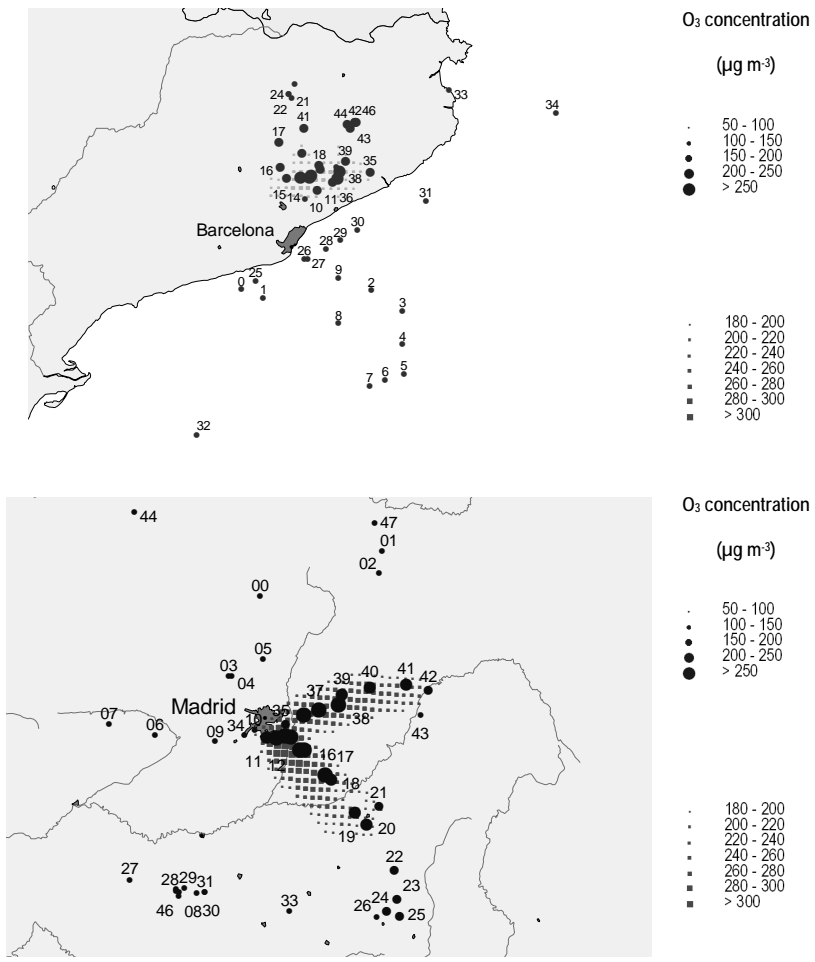

Fig. 4. Hourly maximum $\mathrm{O}_{3}$ surface concentration location (circles) in the coastal (up) and the central (down) domains during the 17-18 June, 2004 episode, simulated by WRF-ARW/HERMES2004/CMAQ. Squares: concentrations above the EU human health protection limit (180 $\mathrm{g} \mathrm{m}^{-3}$, Dir 2002/3/EC).

exceeding in some cases the population information threshold $\left(180 \mu \mathrm{g} \mathrm{m}^{-3}\right)$. The gas-phase chemistry accounts in these cases for 50 to $75 \mu \mathrm{g} \mathrm{m}^{-3} \mathrm{~h}^{-1}$ in the first layer cells. In the urban areas and main roads, as main sources of $\mathrm{NO}_{\mathrm{x}}$, chemical destruction of $\mathrm{O}_{3}$ occurs up to $-200 \mu \mathrm{g} \mathrm{m}^{-3}$ per hour during the traffic circulation peaks. The vertical gradients of $\mathrm{O}_{3}$ concentration generated in these areas, larger during daytime, increase the contribution of diffusion processes to ground-level $\mathrm{O}_{3}$ (up to $200 \mu \mathrm{g} \mathrm{m}^{-3} \mathrm{~h}^{-1}$ fluxes, mainly from upper vertical layers). Surface $\mathrm{O}_{3}$ concentrations are larger in the continental than in the coastal domain. While in the NEIP the breezes and mountain-valley winds regime involves the accumulation and recirculation of pollutants aloft, in the CIP the main flows are dominated by thermal phenomena that transport pollutants within the convective recirculation cell. The PBL height reaches its maximum at midday, being higher in the central-continental domain around $3200 \mathrm{~m}$ a.g.l. - than in the coastal domain - maximum around $2000 \mathrm{~m}$ a.g.l., due to the lamination of the PBL growth by the Mediterranean Sea breezes.

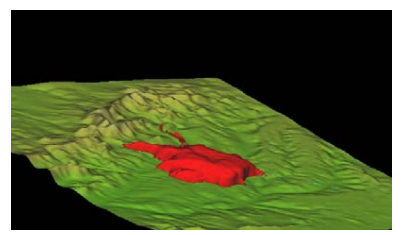

17/06/2004 10:00 UTC

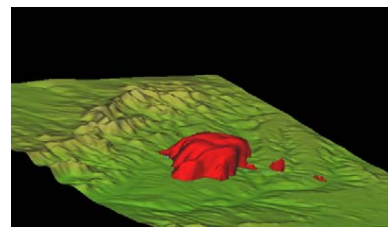

18/06/2004 1000 UTC

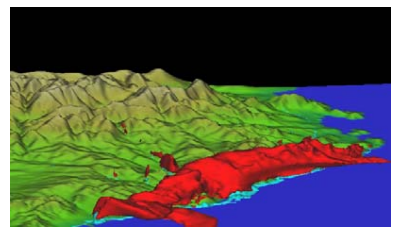

17/06/2004 1000 UTC

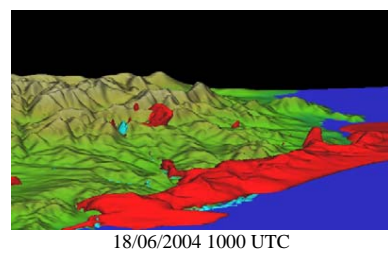

18/06/2004 1000 UTC

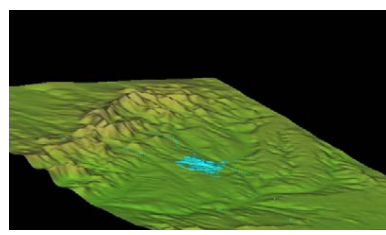

17/06/2004 18:00 UTC

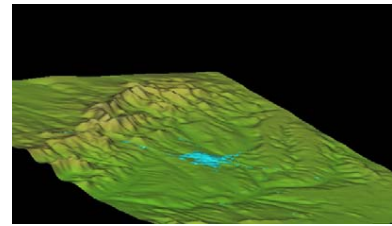

18/06/2004 1800 UTC

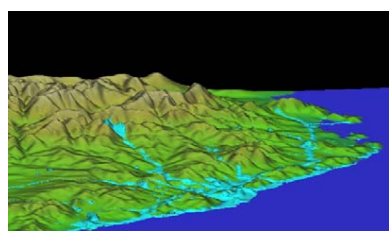

17/06/2004 1800 UTC

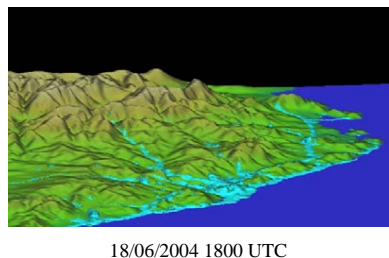

18/06/2004 1800 UTC
Fig. 5. $10 \mu \mathrm{g} \mathrm{m}^{-3}$ isosurface of chemical production (red) and destruction (blue) of $\mathrm{O}_{3}$ for the CIP (up) and NEIP domains (down) at 10:00 and 18:00 UTC of the 17-18 June, 2004.

The emitted $\mathrm{NO}_{\mathrm{x}}$ and NMVOCs in the central-continental domain during the morning react forming $\mathrm{O}_{3}$, the surface heating generates a convective cell and the photochemical pollution plume rises, reaching 2500-3000 m a.g.l. (Figs. 56 ) and moves downwind, affecting the southern area during the 17 June and the eastern area on the 18 June. The maximum surface $\mathrm{O}_{3}$ concentrations occur at midday (from 13:00 to 16:00 UTC of 17 June and 12:00 to 14:00 UTC of 18 June). During the afternoon and dusk the convective cell weakens and falls over the Madrid downwind areas, the PBL height reduction involves high $\mathrm{O}_{3}$ surface concentrations even when the photochemical production diminishes. At night-time, the $\mathrm{O}_{3}$ generation ceases, and the concentration of photochemical pollutants decays. The katabatic winds dominant in the Central system area enhance the effect of the wind shift, being the main flows channelled by the Tajo valley towards the south-western area (hourly maximum concentrations in this period are located in this area, see Fig. 4).

The coastal domain behaviour differs, being more favourable to several days photochemical episodes, due to the reservoir layers formed over the Mediterranean Sea during night-time (Figs. 5-6). Specifically, the main emission sources are located in the coastal area. When the mesoscale 
phenomena dominate the pollutants transport, the breeze regime development in during the morning transports the primary pollutants inland. The littoral mountain chain acts as a barrier at dawn, recirculating the pollutants towards the Mediterranean Sea; these return flows are enhanced by the development of anabatic winds. As the day advances the sea breeze regime develops and reaches the Pre-littoral chain, higher than the previous $(1000-1500 \mathrm{~m})$, producing a second recirculation flow aloft. On the other hand, the river valleys and main roads act channelling the pollutants flow inland. The pollution plume reaches flat inland areas, where it accumulates during the afternoon and dusk, because of the Pyrenees barrier cutting the flows to the northern area. In fact maximum $\mathrm{O}_{3}$ surface concentrations during the episode are reached in the 12:00-14:00 UTC period in north-eastern areas from the Barcelona conurbation and maximum hourly concentrations in the 18:00-21:00 UTC period are found in the northern domain (in the Pre-Pyrenees region) (Fig. 4). When the mesoscale wind regime shifts, katabatic winds and land breezes involve a return flow of the pollutants plume over the Mediterranean Sea. Moreover, previous studies (e.g. Jiménez et al., 2006) have detected a layer of pollutants outbreak in altitude with peninsular origin (3000-3500 m a.g.l.) that contributes in this kind of episodes to the high concentration of pollutants in the area.

On the other hand, the urban plume reactivity differs, being the Madrid airshed more favourable to $\mathrm{O}_{3}$ formation in situ, while in Barcelona $\mathrm{O}_{3}$ titration by $\mathrm{NO}_{\mathrm{x}}$ emissions involves a sink of $\mathrm{O}_{3}$ in the surface layer. Formation occurs mainly in upper levels and in areas located around $100 \mathrm{~km}$ away from the city (Fig. 5).

In summary, the main contributors to $\mathrm{O}_{3}$ surface concentrations are the net transport and vertical diffusion, while the main sink is dry deposition. The wet deposition and cloud processes are negligible during the episode, due to the low cloudiness and the absence of precipitation, typical in a summertime period such as the one studied. The aerosols interaction with photochemical gaseous pollutants is also negligible. The chemical contribution differs depending on the location and the $\mathrm{NO}_{\mathrm{x}}-\mathrm{VOCs}$ ratio. The process analysis indicates that maximum chemical production of $\mathrm{O}_{3}$ does not occur in the first vertical layer of the model, but in layers aloft during the morning and central hours of the day (Fig. 5). This effect will be deeply discussed in the next section. The horizontal and vertical advective transport determine the areas that will be affected by these pollutants, being the transport patterns much simpler in the central domain than in the coastal area, where stratified layers and accumulation of pollutants are frequent during summertime episodes with stagnant conditions, as shown in Fig. 6. The process analysis confirms the results of previous experimental and modelling studies carried out in these areas (e.g. Baldasano et al., 1994; Millán et al., 1997; Soriano et al., 2001; Pérez et al., 2004; Jiménez et al., 2006).

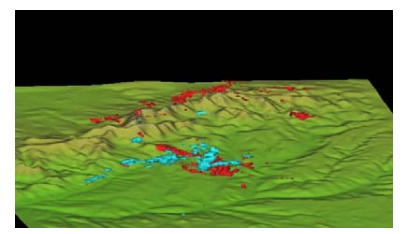

17/06/2004 10:00 UTC

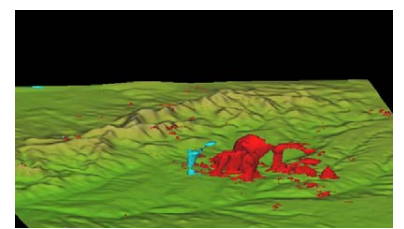

18/06/2004 1000 UTC

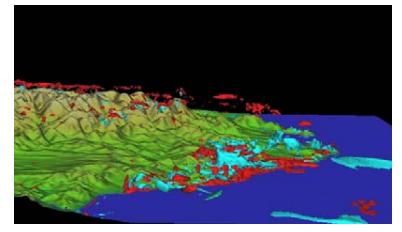

17/06/2004 1000 UTC

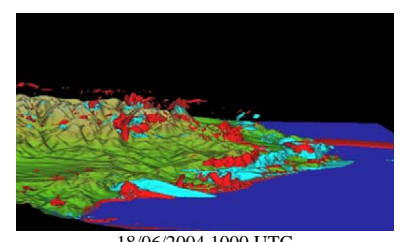

18/06/2004 1000 UTC

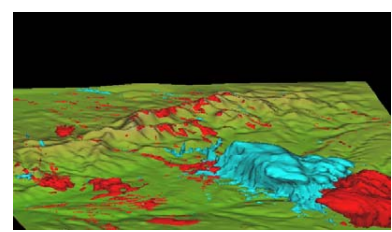

17/06/2004 18:00 UTC

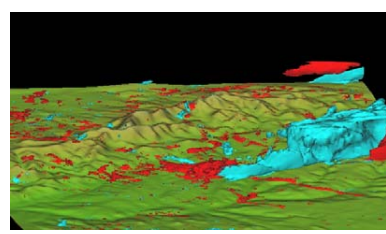

18/06/2004 1800 UTC

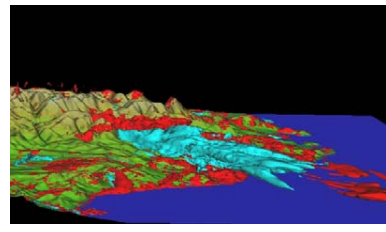

17/06/2004 1800 UTC

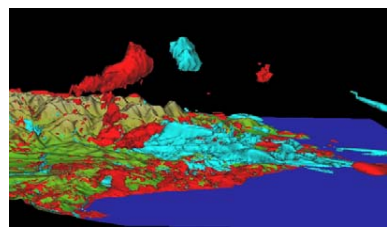

18/06/2004 1800 UTC
Fig. 6. $10 \mu \mathrm{g} \mathrm{m}^{-3}$ isosurface of $\mathrm{O}_{3}$ net transport (horizontal + vertical advection) - positive contribution in red and negative contribution in blue - for the CIP (up) and NEIP domains (down) at 10:00 and 18:00 UTC of the 17-18 June, 2004.

\subsection{Processes contribution to $\mathrm{O}_{3}-\mathrm{NO}_{\mathrm{x}}-\mathrm{NMVOCs}$ concen- trations}

In order to define the origins of maximum $\mathrm{O}_{3}$ concentrations in the coastal and continental domains, two subdomains $\left(20 \times 10 \mathrm{~km}^{2}\right)-$ MAX1 and MAX2- are defined considering the areas where the maximum concentrations are estimated by the model on the first and second day of the episode, respectively (Fig. 7). The $\mathrm{O}_{3}, \mathrm{NO}, \mathrm{NO}_{2}$ and NMVOCs density $\left(\mathrm{g} \mathrm{m}^{-2}\right)$ in the atmospheric column under the PBL is assessed together with the contributions of different processes leading to these levels. All values are obtained as an hourly average for the whole subdomain areas $\left(200 \mathrm{~km}^{2}\right)$. The night-time modelled PBL height (Fig. 7) is near surface level (around $20 \mathrm{~m}$ a.g.l.), then the pollutants density and processes contribution are negligible versus those of daytime periods.

The $\mathrm{O}_{3}$ maximum concentrations during the 17 June occur in the MAX1 domains. In the costal-MAX1 the horizontal advective transport to the area constitutes the major positive contribution to net $\mathrm{O}_{3}$ until 16:00 UTC $\left(0.042 \mathrm{~g} \mathrm{~m}^{-2} \mathrm{~h}^{-1}\right.$ on average from 09:00 to 16:00 UTC). There is also a significant vertical advective transport removing $\mathrm{O}_{3}$ from 

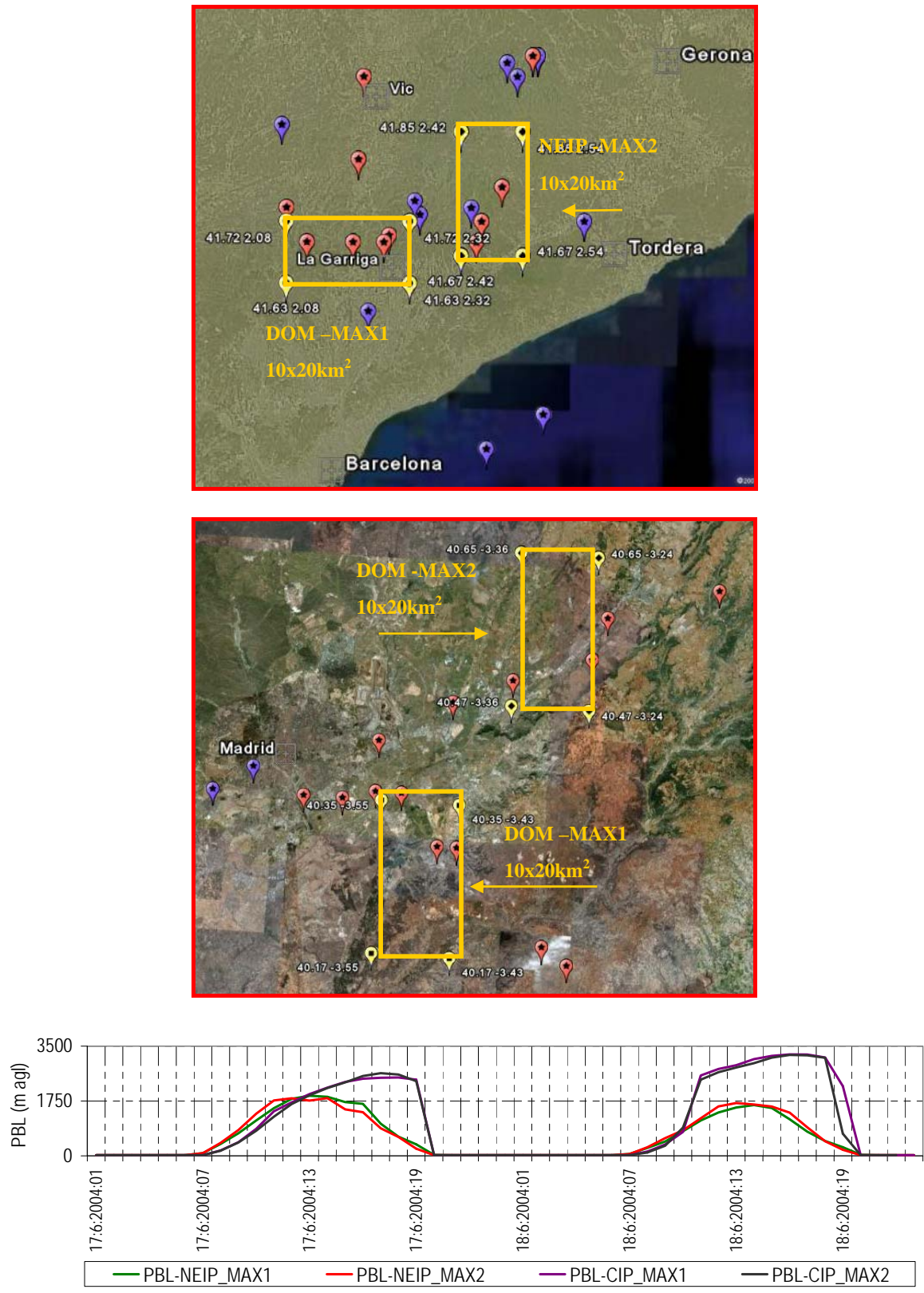

Fig. 7. Subdomains MAX1 and MAX2 (in yellow) selected in the NEIP (up) - MAX1: LAT: 41.63-41.72, LON: 2.08-2.32; MAX2: LAT: 41.67-41.85, LON: 2.42-2.54 - and CIP domains (down) - MAX1: LAT: 40.17-40.35, LON: -3.55-(-3.43); MAX2: LAT: 40.47-40.65; $-3.36-(-3.24)$. Maximum hourly concentrations above $180 \mu \mathrm{g} \mathrm{m}^{-3}$ in red, concentrations below this limit in purple. Evolution of the modelled PBL height in the NEIP and CIP subdomain.

the PBL $\left(-0.052 \mathrm{~g} \mathrm{~m}^{-2} \mathrm{~h}^{-1}\right)$. Later on, until 19:00 UTC, the horizontal advective flows remove $\mathrm{O}_{3}$ from this area $\left(0.057 \mathrm{~g} \mathrm{~m}^{-2} \mathrm{~h}^{-1}\right.$ on average), due to the transport of the pollutants plume towards the Mediterranean Sea. The $\mathrm{O}_{3}$ chemical production from 07:00 to 17:00 UTC is the second source of importance $\left(0.019 \mathrm{~g} \mathrm{~m}^{-2} \mathrm{~h}^{-1}\right)$. The continental-MAX1 domain presents a similar behaviour, being the horizontal advective transport the most important positive contribution to net $\mathrm{O}_{3}$ until 15:00 UTC, on average $0.042 \mathrm{~g} \mathrm{~m}^{-2} \mathrm{~h}^{-1}$ (Fig. 8). Then, the wind shift involves a negative contribution of horizontal advection until 19:00 UTC $\left(-0.079 \mathrm{~g} \mathrm{~m}^{-2} \mathrm{~h}^{-1}\right)$. In this case there are no important vertical injections, being the contributions of vertical advection almost negligible compared to horizontal advection and chemical production (i.e. vertical transport causes a removal of $-0.006 \mathrm{~g} \mathrm{~m}^{-2} \mathrm{~h}^{-1}$ on average in the 11:00 to 15:00 UTC period). The complex 

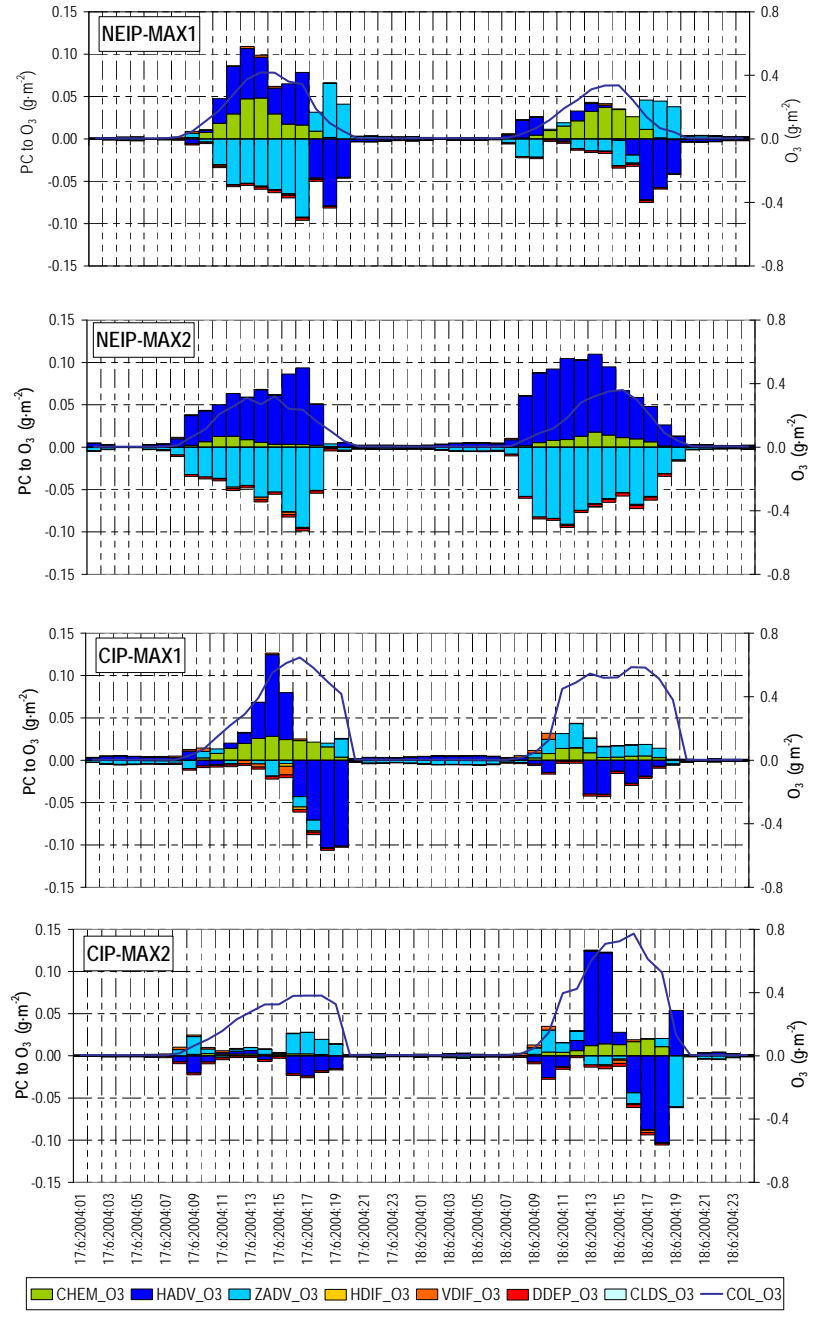

Fig. 8. Atmospheric processes contribution (PC) to net $\mathrm{O}_{3}$ density $\left(\mathrm{g} \mathrm{m}^{-2}\right)$ under the modelled PBL during the 17-18 June, 2004. Averaged contributions for the NEIP-MAX1 and MAX2 domains, and CIP-MAX1 and MAX2 domains.

topography in the coastal area explains, as already commented, the vertical transport flows of pollutants caused by the breeze regimes mechanically enhanced by the mountain chains located along the coast. Meanwhile, in the continental domain the vertical flows promote the transport of pollutants under the PBL; these are thermally produced and they have no orographic forcing involving injections in upper levels.

On the other hand, the MAX2 subdomains stand for the locations of maximum $\mathrm{O}_{3}$ concentrations during the second day of the episode. As discussed for the first day, the contributions to net $\mathrm{O}_{3}$ density are mainly transport; the continuous horizontal advective flows involve high $\mathrm{O}_{3}$ densities in the coastal-MAX2 subdomain (horizontal transport contributes on average with $0.064 \mathrm{~g} \mathrm{~m}^{-2} \mathrm{~h}^{-1}$ during the $08: 00$ to 19:00 UTC period). Once again, the vertical injections are
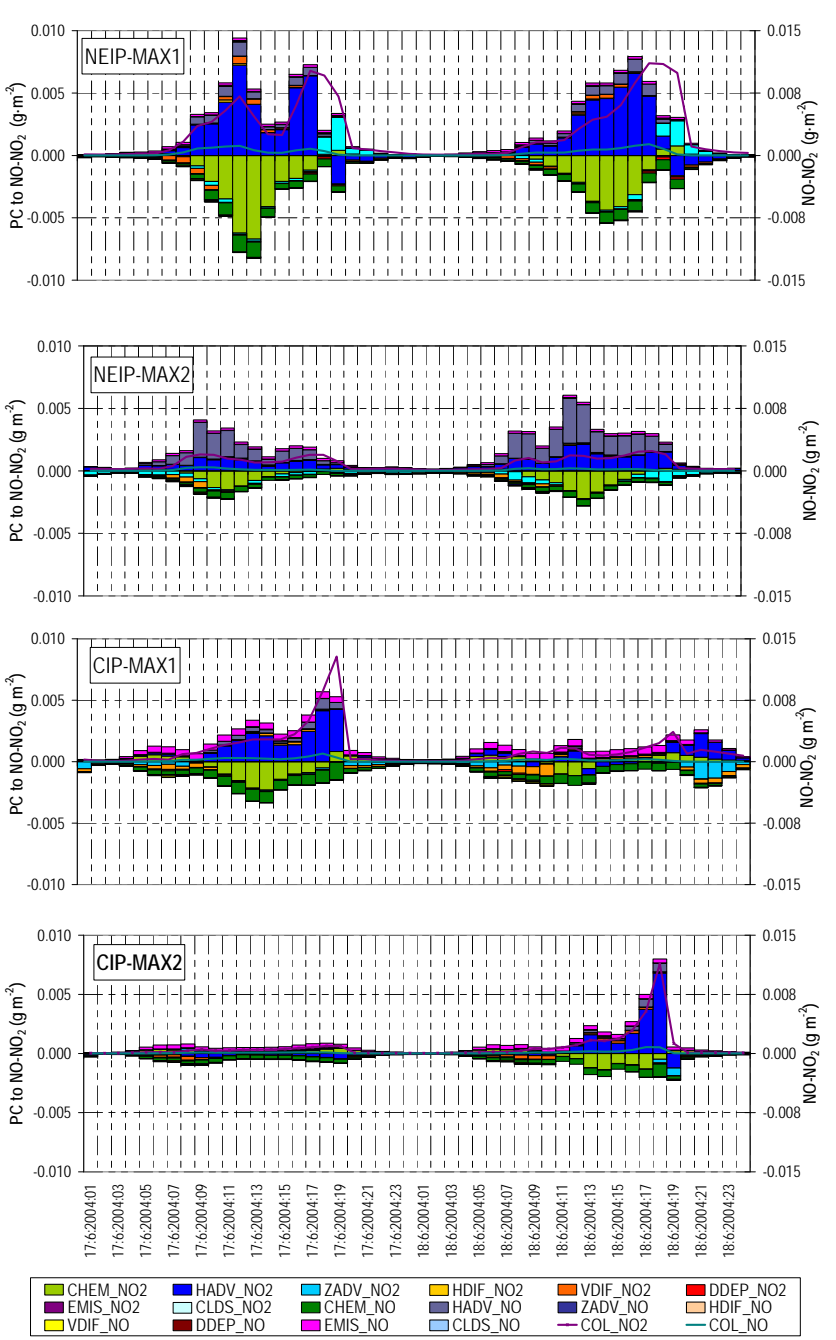

Fig. 9. Atmospheric processes contribution $(\mathrm{PC})$ to net $\mathrm{NO}_{\mathrm{x}}$ density $\left(\mathrm{g} \mathrm{m}^{-2}\right)$ under the modelled PBL during the 17-18 June, 2004. Averaged contributions for the NEIP-MAX1 and MAX2 domains, and CIP-MAX1 and MAX2 domains.

the major sink of $\mathrm{O}_{3}$ in the region $\left(-0.062 \mathrm{~g} \mathrm{~m}^{-2} \mathrm{~h}^{-1}\right.$ on average). Chemical production in this case is lower than in areas nearer from the Barcelona urban area, such as MAX1 domain $\left(0.009 \mathrm{~g} \mathrm{~m}^{-2} \mathrm{~h}^{-1}\right.$ on average), and the $\mathrm{O}_{3}$ concentrations estimated by the model are clearly affected by horizontal advection. The continental-MAX2 domain is characterized by an important horizontal advection during the central hours of the day, from 12:00 to 15:00 UTC contributing with $0.062 \mathrm{~g} \mathrm{~m}^{-2} \mathrm{~h}^{-1}$ on average; then the horizontal flows remove $\mathrm{O}_{3}$ from the domain $\left(-0.078 \mathrm{~g} \mathrm{~m}^{-2} \mathrm{~h}^{-1}\right.$ until 18:00 UTC). The relatively high $\mathrm{O}_{3}$ density observed from 14:00 to $16: 00 \mathrm{UTC}$ is due to the chemical production $\left(0.015 \mathrm{~g} \mathrm{~m}^{-2} \mathrm{~h}^{-1}\right.$ from 13:00 to 18:00 UTC) and the larger integration height (PBL height 3134 to $3220 \mathrm{~m}$ a.g.l. as observed in Fig. 7) considered. 

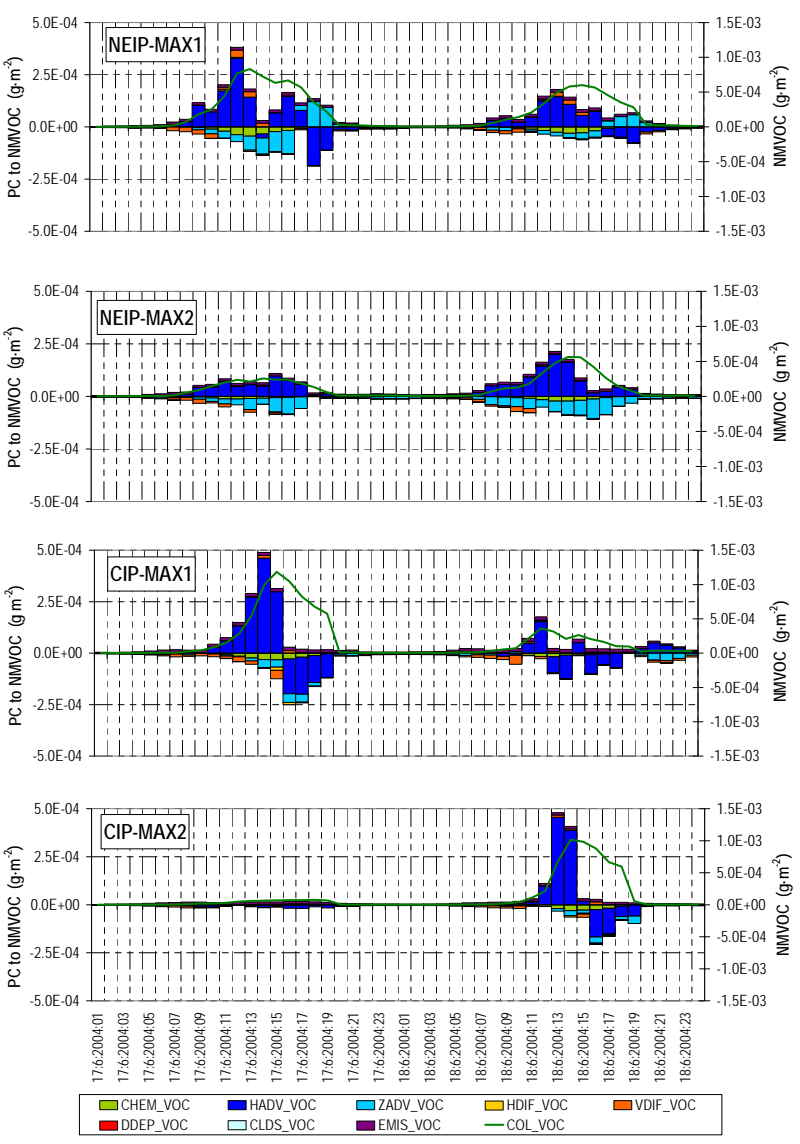

Fig. 10. Atmospheric processes contribution to net NMVOCs density $\left(\mathrm{g} \mathrm{m}^{-2}\right)$ under the modelled PBL during the 17-18 June, 2004. Averaged contributions for the NEIP-MAX1 and MAX2 domains, and CIP-MAX1 and MAX2 domains.

The NEIP subdomains (coastal) are characterized by the low weight of emissions in the $\mathrm{NO}_{\mathrm{x}}$ budget under the PBL (Fig. 9) when compared to CIP (continental). Specifically in the NEIP-MAX1, the horizontal advection is the main source of $\mathrm{NO}-\mathrm{NO}_{2}$ until 16:00 UTC $\left(3.4 \times 10^{-4}\right.$ and $0.0022 \mathrm{~g} \mathrm{~m}^{-2} \mathrm{~h}^{-1}$, respectively) and chemical reaction involves the main sink of these oxides $\left(-4.4 \times 10^{-4}\right.$ and $-0.0016 \mathrm{~g} \mathrm{~m}^{-2} \mathrm{~h}^{-1}$, respectively). From then on the horizontal transport removes $\mathrm{NO}_{2}$ and vertical transport from layers above the PBL contributes positively until 18:00 UTC. While NO continues oxidizing and chemical destruction is still the main sink of this compound, from 18:00 to 20:00 UTC net chemical production of $\mathrm{NO}_{2}$ in situ is observed $\left(2.07 \times 10^{-4} \mathrm{~g} \mathrm{~m}^{-2} \mathrm{~h}^{-1}\right)$. The minimum $\mathrm{NO}_{\mathrm{x}}$ density observed on 17 June around 15:00-16:00 UTC reflects the direct effect of the peaks of traffic emissions during the early morning and the afternoon in closer areas (such as Barcelona city), which is the main origin of the advected $\mathrm{NO}_{\mathrm{x}}$.
The CIP subdomains present a similar behaviour concerning $\mathrm{NO}_{\mathrm{x}}$ (Fig. 9), being the major source the horizontal advection from surrounding areas $\left(2.0 \times 10^{-4} \mathrm{~g} \mathrm{~m}^{-2} \mathrm{~h}^{-1}\right.$ for $\mathrm{NO}$ and $0.0011 \mathrm{~g} \mathrm{~m}^{-2} \mathrm{~h}^{-1}$ for $\mathrm{NO}_{2}$ until 19:00 UTC) and the main sinks the gas-phase chemical reactions $\left(-5.8 \times 10^{-4} \mathrm{~g} \mathrm{~m}^{-2} \mathrm{~h}^{-1}\right.$ and $-4.2 \times 10^{-4} \mathrm{~g} \mathrm{~m}^{-2} \mathrm{~h}^{-1}$, respectively). Nevertheless the emissions of NO have limited importance in these subdomains, and specifically in the CIPMAX1 domain, where NO emissions contribute with an approximately constant density, from 04:00 to 19:00 UTC $\left(4.9 \times 10^{-4} \mathrm{~g} \mathrm{~m}^{-2} \mathrm{~h}^{-1}\right)$. The increase in $\mathrm{NO}_{2}$ density during the 15:00-18:00 UTC period due to the advective transport and the lower chemical destruction may be related to the high $\mathrm{O}_{3}$ density observed. The $\mathrm{NO}_{\mathrm{x}}$ levels in the central-MAX2 domain are low during the 17 June and increase considerably by horizontal advection during the 18 June. In the early morning (until 10:00 UTC) losses of $\mathrm{NO}_{\mathrm{x}}$ by vertical diffusion $\left(-2.8 \times 10^{-5} \mathrm{~g} \mathrm{~m}^{-2} \mathrm{~h}^{-1}\right.$ for $\mathrm{NO}$ and $-1.2 \times 10^{-4} \mathrm{~g} \mathrm{~m}^{-2} \mathrm{~h}^{-1}$ for $\mathrm{NO}_{2}$ ) to upper layers are estimated by the model.

In the coastal-MAX1 domain the NMVOCs levels are relatively high (Fig. 10). Horizontal advection until 17:00 UTC (contributing on average with $7.5 \times 10^{-5} \mathrm{~g} \mathrm{~m}^{-2} \mathrm{~h}^{-1}$ ) and vertical advection from upper layers until 19:00 UTC $\left(3.6 \times 10^{-5} \mathrm{~g} \mathrm{~m}^{-2} \mathrm{~h}^{-1}\right)$ are their main sources. The daytime average contribution of emissions is low and accounts for $1.2 \times 10^{-5} \mathrm{~g} \mathrm{~m}^{-2} \mathrm{~h}^{-1}$. During the morning, until 10:00 UTC, some NMVOCs are injected in layers above the PBL by vertical diffusion $\left(-1.5 \times 10^{-5} \mathrm{~g} \mathrm{~m}^{-2} \mathrm{~h}^{-1}\right)$ and vertical advective processes $\left(-2.5 \times 10^{-5} \mathrm{~g} \mathrm{~m}^{-2} \mathrm{~h}^{-1}\right.$ on average until 16:00 UTC), involving a sink of these organic compounds, together with chemical reaction $\left(-1.3 \times 10^{-5} \mathrm{~g} \mathrm{~m}^{-2} \mathrm{~h}^{-1}\right.$ on average during daytime). Nevertheless, the net transport (advection and diffusion) involves a positive contribution during daytime on average of $3.8 \times 10^{-5} \mathrm{~g} \mathrm{~m}^{-2} \mathrm{~h}^{-1}$. From 11:00 UTC the vertical diffusion contributes positively to the NMVOCs density under the PBL, nevertheless its contribution is almost negligible compared to the net transport by advection. The NEIP-MAX2 behaviour is more homogeneous, being the horizontal advective flows the main contributors to net NMVOCs density under the PBL $\left(5.6 \times 10^{-5} \mathrm{~g} \mathrm{~m}^{-2} \mathrm{~h}^{-1}\right)$ and vertical advection the main sink $\left(-3.8 \times 10^{-5} \mathrm{~g} \mathrm{~m}^{-2} \mathrm{~h}^{-1}\right)$, together with chemical reaction $\left(-6.5 \times 10^{-6} \mathrm{~g} \mathrm{~m}^{-2} \mathrm{~h}^{-1}\right)$ and vertical diffusion specially during the morning $\left(-1.3 \times 10^{-5} \mathrm{~g} \mathrm{~m}^{-2} \mathrm{~h}^{-1}\right.$ until 11:00 UTC).

The horizontal advection affecting the CIP-MAX1 domain during 17 June involves the largest contribution to net NMVOCs density under the PBL until 16:00 UTC (Fig. 10, average contribution of $1.27 \times 10^{-4} \mathrm{~g} \mathrm{~m}^{-2} \mathrm{~h}^{-1}$ ), then the winds shift removes these compounds by the same process. The chemical destruction reaches its maximum during the 14:00-15:00 UTC, accounting for $-2.0 \times 10^{-5} \mathrm{~g} \mathrm{~m}^{-2} \mathrm{~h}^{-1}$. Vertical advection and diffusion remove NMVOCs from the PBL, but in a lower extent. The specific study area is not characterized by a high emissions rate; therefore 
the contribution of this process is almost negligible compared to transport processes. The CIP-MAX2 presents a similar behaviour during the 18 June, when it is directly affected by the horizontal advective flows. The winds shift occurs one hour earlier, being the horizontal transport the main sink of NMVOCs in the area from 16:00 UTC $\left(-6.5 \times 10^{-5} \mathrm{~g} \mathrm{~m}^{-2} \mathrm{~h}^{-1}\right)$. The maximum removal by chemical destruction also occurs in the 14:00-15:00 UTC period $\left(-1.7 \times 10^{-5} \mathrm{~g} \mathrm{~m}^{-2} \mathrm{~h}^{-1}\right)$.

Differences in chemical behaviour are observed for the studied domains (Fig. 11). The coastal domains present similar chemical behaviours; the NMVOCs are the only locally emitted precursors, which react with transported $\mathrm{NO}_{\mathrm{x}}$ generating $\mathrm{O}_{3}$ by gas-phase chemistry. The CIP-MAX1 domain includes emitters of $\mathrm{NO}_{\mathrm{x}}$ and NMVOCs, which react forming $\mathrm{O}_{3}$, nevertheless the $\mathrm{O}_{3}$ chemistry does not involve destruction of NMVOCs in the same magnitude as the coastal domains. In absence of solar radiation, when the $\mathrm{O}_{3}$ stopped forming, the $\mathrm{NO}$ oxidation continues producing net $\mathrm{NO}_{2}$ (18:00-19:00 UTC period). In the CIP-MAX2 domain the emissions are an important source of NMVOCs. These are chemically destroyed in the 10:00 to 19:00 UTC period on 17 June, being the generation of $\mathrm{O}_{3}$ by chemistry relatively low. The low contribution of net transport of $\mathrm{NO}_{\mathrm{x}}$ and the absence of emissions of this compounds in the area may be the main causes for the low $\mathrm{O}_{3}$ production. On the second day of the episode the horizontal advection directly affect the MAX2 involving a much higher net chemical production of $\mathrm{O}_{3}$, being the chemical oxidation of NMVOCs lower.

\section{Conclusions}

The Integrated Process Rate implemented in the CMAQ model was applied to obtain quantitative information about simulated atmospheric processes affecting the concentration of pollutants in typical coastal and continental environments located in south-western Europe: the North-Eastern Iberian Peninsula (NEIP) and Central Iberian Peninsula (CIP) domains, respectively. A representative summertime photochemical pollution episode characterized by stagnant conditions over the area was selected.

The model performance agrees with European Directives recommendations, nevertheless specifically in background air quality stations tends to overestimate the $\mathrm{O}_{3}$ morning concentrations and underestimate the $\mathrm{O}_{3}$ levels during the afternoon. The findings of this work together with previous studies results allow us to depict the main causes for these deviations, being aware that there is not an unique reason for a model failure in predictions. The chemical destruction may be underpredicted during night-time, which favours the high estimated morning concentrations. Moreover the overpredicted flows during the afternoon and dusk and nighttime could cause an enhanced venting of pollutants. The mesoscale meteorological models have shown inaccuracies
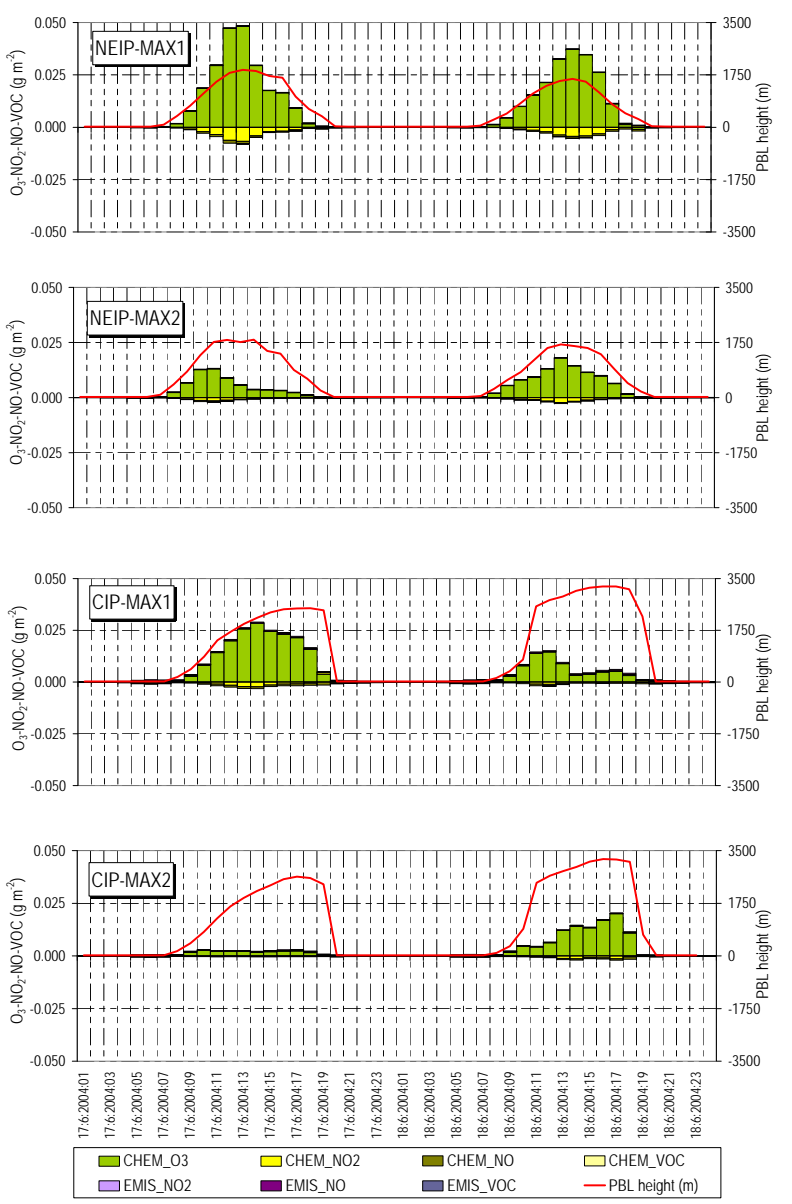

Fig. 11. Gas-phase chemistry and emissions contributions to net $\mathrm{NO}_{\mathrm{x}}-\mathrm{NMVOCs}-\mathrm{O}_{3}$ density $\left(\mathrm{g} \mathrm{m}^{-2}\right)$ under the modelled PBL height (in red) during the 17-18 June, 2004 for the NEIP-MAX1 and MAX2 domains, and the CIP-MAX1 and MAX2 domains.

in predicting wind flows during the dominant stagnant conditions; which together with the underestimations in the emissions account play a fundamental role in these deviations. $\mathrm{NO}_{2}$ is clearly linked to $\mathrm{O}_{3}$, with both inaccuracies in transport and chemical behaviour being on the origin of the errors in the simulated concentrations. On the other hand, $\mathrm{O}_{3}$ peaks and $\mathrm{NO}_{2}$ underprediction in the coastal domain may be related to difficulties for the model to define the accumulation layers formed and characteristic recirculation of pollutants due to the very complex terrain. In the case of $\mathrm{SO}_{2}$ and $\mathrm{PM}_{10}$ a slight underestimation of emissions could be the main cause for the underestimation of these pollutants.

Applying the Integrated Process Rate tool to the first vertical layer simulated provides information about the surface concentration of pollutants estimated by the model. In order to perform a deeper study of the contributions of main atmospheric processes leading to the levels of these pollutants the vertical component has to be considered. In this work 
the whole atmospheric column under the PBL is selected, reflecting that chemistry and transport patterns vary with height.

The process analysis indicates that the maximum concentration of photochemical pollutants occur due to transport phenomena. Specifically in the coastal domain (NEIP), the high surface $\mathrm{O}_{3}$ levels are not produced in situ, but come from horizontally advected flows during the morning and gas-phase chemical contributions occurring aloft. During the afternoon and dusk vertical advective flows inject the pollutants in layers above the PBL, which accumulate due to the stagnant conditions over the region and contribute positively to surface concentrations the next simulated day. The centralcontinental domain (CIP) behaviour slightly differs: the horizontal advection is also the main contributor to $\mathrm{O}_{3}$ surface concentrations, but the chemical formation takes place in the whole vertical column below the PBL. The transport patterns differ between the coastal and the continental area, where the $\mathrm{O}_{3}$ precursors are homogeneously distributed in the whole atmospheric column under the PBL and vertical injections of pollutants above the PBL are less frequent.

The dry deposition is an important sink for pollutants in the lowest layer of the model, coupled in the present simulation with vertical diffusion flows. In spite of the stagnant conditions dominating during the episode, the diffusive processes contributions to net pollutants concentrations under the PBL are relatively low, and in particular the horizontal diffusion is negligible compared to other atmospheric processes. Vertical diffusion compensates the loss of $\mathrm{O}_{3}$ in surface layers due to $\mathrm{NO}$ titration, contributing positively to net $\mathrm{O}_{3}$ concentrations in the road network and urban areas. The $\mathrm{O}_{3}$ peaks at surface level are higher in the CIP domain, mainly due to the much simpler transport pattern compared to the coastal region, which implies that almost all the chemically produced $\mathrm{O}_{3}$ under the PBL contributes to surface concentrations when the convective cell weakens. Controlling emissions of precursors in both domains is a decisive factor in order to abate photochemical pollution episodes during summertime. The emitted NMVOCs have mainly a biogenic origin and therefore policies focused on reducing $\mathrm{NO}_{\mathrm{x}}$ emissions must be addressed in these regions. Finally, the cloud processes, wet deposition and heterogeneous chemistry contributions are negligible during the whole episode, characterized by a high solar radiation and no precipitation or cloudiness.

This work explores the possibilities of applying process analysis to high resolution simulations proving that it could be useful not only to better evaluate the simulation results, but also to perform more accurate source apportionment of pollutants over a region.

Acknowledgements. The authors gratefully acknowledge E. López for the implementation of HERMES, O. Jorba for the meteorological input data and T. Loridan for his help in generating 3D images. This work was funded by the projects CICYT CGL2006-08903 and CGL2006-11879 of the Spanish Ministry of Education and Science and CALIOPE project 441/2006/3-12.1 of the Spanish Ministry of the Environment. Simulations were carried out in the MareNostrum supercomputer: 94.21 Teraflops of theoretical performance peak; 10240 processors PowerPC 970MP (2560 JS21 blades); Fig. 7 was obtained from Google Maps, (C) 2007 - Images DigitalGlobe, Terrametrics, NASA.

Edited by: J. Brandt

\section{References}

Arévalo, G., Salvador, R., Gasso, S., Millan, M., and Baldasano, J. M.: Application of a high-resolution emission model in Valencia Community (Spain), in: Air Pollution XII, edited by: BREBBIA WITpress, Rhodes, Greece, 14, 31-40, 2004.

Baldasano, J. M., Cremades, L., and Soriano, C.: Circulation of Air Pollutants over the Barcelona Geographical Area in Summer, in: Proceedings of Sixth European Symposium Physico-Chemical Behaviour of Atmospheric Pollutants, Varese (Italy), 18-22 October, 1993, Report EUR 15609/1 EN, 474-479, 1994.

Baldasano, J. M., Güereca, P., López, E., Gassó, S., and JiménezGuerrero, P.: Development of a high resolution $(1 \mathrm{~km} \times 1 \mathrm{~km}, 1 \mathrm{~h})$ emission model for Spain: the High-Elective Resolution Modelling Emission System (HERMES), Atmos. Environ., 42, 72157233, 2008.

Barros, N., Borrego, C., Toll, I., Soriano, C., Jiménez, P., and Baldasano, J. M.: Urban Photochemical Pollution in the Iberian Peninsula: Lisbon and Barcelona Airsheds, J. Air Waste Manage., 53, 347-359, 2003.

Byun, D. W. and Schere, K. L.: Review of the governing equations, computational algorithms and other components of the Models-3 Community Multiscale Air Quality (CMAQ) Modeling System, Appl. Mech. Rev., 59(2), 51-77, 2006.

Colella, P. and Woodward, P. L.: The piecewise parabolic method (PPM) for gas-dynamical simulations, J. Comput. Phys., 54, 174-201, 1984.

Coll, I., Pinceloup, S., Perros, P. E., Laverdet, G., and Le Bras, G.: $3 \mathrm{D}$ analysis of high ozone production rates observed during the ESCOMPTE campaign, Atmos. Res., 74, 477-505, 2005.

Cousin, F., Tulet, P., and Rosset, R.: Interaction between local and regional pollution during ESCOMPTE 2001: impact on surface ozone concentrations (IOP2a and 2b), Atmos. Res., 74, 117-137, 2005.

Cros, B., Durand, P., Cachier, H., Drobinski, Ph., Fréjafon, E., Kottmeier, C., Perros, P. E., Peuch, V.-H., Ponche, J.-L., Robin, D., Saïd, F., Toupance, G., and Wortham, H.: The ESCOMPTE program: an overview, Atmos. Res., 69, 241-279, 2004.

Dufour, A., Amodei, M., Ancellet, G., and Peuch, V.-H.: Observed and modelled chemical weather during ESCOMPTE, Atmos. Res., 74, 161-189, 2005.

EC: Directive 2008/50/EC of the European Parliament and of the Council of 21 May 2008 on ambient air quality and cleaner air for Europe, Official Journal of the European Union, 11 June 2008, 44 pp., 2008.

Gipson, L. G.: Science Algorithms of the EPA Models-3 Community Multiscale Air Quality (CMAQ) Modeling System: process analysis, EPA/600/R-99/030, US-EPA, online available at: http:// 
www.epa.gov/asmdnerl/CMAQ/CMAQscienceDoc.html, 37 pp., 1999.

Gery, M. W., Whitten, G. Z., Killus, J. P., and Dodge, M. C.: A photochemical kinetics mechanism for urban and regional scale computer modeling, J. Geophys. Res., 94(12), 925-956, 1989.

Hauglustaine, D. A. and Brasseur, G. P.: Evolution of tropospheric ozone under anthropogenic activities and associated radiative forcing on climate, J. Geophys. Res., 106, 32337-32360, 2001.

Hertel, O., Berkowicz, R., Christensen, J., and Hov, O.: Test of two numerical schemes for use in atmospheric transport-chemistry models, Atmos. Environ., 27A, 2591-2611, 1993.

Hogrefe, C., Lynn, B., Rosenzweig, C., Goldberg, R., Civerolo, K., Ku, J.-Y., Rosenthal, J., Knowlton, K., and Kinney, P. L.: Utilizing CMAQ process analysis to understand the impacts of climate change on ozone and particulate matter, in: 4th Annual CMAS Models-3 Users' Conference, 26-28 September 2005, Chapel Hill, NC, USA, 2005.

Huang, J. P., Fung, J., Zhang, Y., Lau, A., and Qin, Y.: Process analysis of different synoptic patterns of $\mathrm{O} 3$ episodes in Hong Kong, in: 86th Annual Meeting of AMS, 28 January-3 February 2006, Atlanta, GA, USA, 2006.

Jang, J. C., Jeffries, H. E., Byun, D., and Pleim, J. E.: Sensitivity of ozone to model grid resolution - I. Application of highresolution regional acid deposition model, Atmos. Environ., 21, 3085-3100, 1995a.

Jang, J. C., Jeffries, H. E., and Tonnesen, S.: Sensitivity of ozone to model grid resolution - II. Detailed process analysis for ozone chemistry, Atmos. Environ., 29, 3101-3114, 1995b.

Jeffries, H. E. and Tonnesen, S.: A comparison of two photochemical reaction mechanisms using mass balance and process analysis, Atmos. Environ., 28, 2991-3003, 1994.

Jiang, G., Lamb, B. and Westberg, H.: Using back trajectories and process analysis to investigate photochemical ozone production in the Puget Sound region, Atmos. Environ., 37, 1489-1502, 2003.

Jiménez, P., Baldasano, J. M., and Dabdub, D.: Comparison of photochemical mechanisms for air quality modelling, Atmos. Environ., 37, 4179-4194, 2003.

Jiménez, P., Jorba, O., Parra, R., and Baldasano, J. M.: Evaluation of MM5-EMICAT2000-CMAQ performance and sensitivity in complex terrain: High-resolution application to the northeastern Iberian Peninsula, Atmos. Environ., 40, 5056-5072, 2005.

Jiménez, P., Lelieveld, J., and Baldasano, J. M.: Multiscale modelling of air pollutants dynamics in the northwestern Mediterranean basin during a typical summertime episode, J. Geophys. Res., 111, D18306, doi:10.1029/2005JD006516, 2006.

Jiménez-Guerrero, P., Jorba, O., Baldasano, J. M., and Gassó, S.: The use of a modeling system as a tool for air quality management: Annual high-resolution simulations and evaluation, Sci. Total Environ., 390, 323-340, doi:10.1016/j.scitotenv.2007.10.025, 2008.

Jonson, J. E., Simpson, D., Fagerli, H., and Solberg, S.: Can we explain the trends in European ozone levels?, Atmos. Chem. Phys., 6, 51-66, 2006, http://www.atmos-chem-phys.net/6/51/2006/.

Jorba, O., Pérez, C., Rocadenbosch, F., and Baldasano, J. M.: Cluster Analysis of 4-Day Back Trajectories Arriving in the Barcelona Area (Spain) from 1997 to 2002, J. Appl. Meteorol., 43(6), 887-901, 2004
Lawrence, M. G., Crutzen, P. J., Rasch, P. J., Eaton, B. E., and Mahowald, N. M.: A model for studies of tropospheric photochemistry: description, global distributions and evaluation, J. Geophys. Res., 104, 26245-26277, 1999.

Lawrence, M. G., Rasch, P. J., von Kuhlmann, R., Williams, J., Fischer, H., de Reus, M., Lelieveld, J., Crutzen, P. J., Schultz, M., Stier, P., Huntrieser, H., Heland, J., Stohl, A., Forster, C., Elbern, H., Jakobs, H., and Dickerson, R. R.: Global chemical weather forecasts for field campaign planning: predictions and observations of large-scale features during MINOS, CONTRACE, and INDOEX, Atmos. Chem. Phys., 3, 267-289, 2003, http://www.atmos-chem-phys.net/3/267/2003/.

Lelieveld, J., Berresheim, H., Borrmann, S., Crutzen, P. J., Dentener, F. J., Fischer, H., Feichter, J., Flatau, P. J., Heland, J., Holzinger, R., Korrmann, R., Lawrence, M. G., Levin, Z., Markowicz, K. M., Mihalopoulos, N., Minikin, A., Ramanathan, V., de Reus, M., Roelofs, G. J., Scheeren, H. A., Sciare, J., Schlager, H., Schultz, M., Siegmund, P., Steil, B., Stepahanou, E. G., Stier, P., Traub, M., Warneke, C., Williams, J., and Zieris, H.: Global air pollution crossroads over the Mediterranean, Science, 298, 794-799, 2002.

Michalakes, J., Dudhia, J., Gill, D., Henderson, T., Klemp, J., Skamarock, W., and Wang, W.: TheWeather Research and Forecasting Model: software architecture and performance, in: Proceedings of the Eleventh ECMWF Workshop on the Use of High Performance Computing in Meteorology, edited by: Zwiefhofer, W. and Mozdzynski, G., World Scientific, European Centre for Medium-Range Weather Forecasts, UK, 156-168, 2004.

Millán, M., Salvador, R., Mantilla, E., and Artíñano, B.: Meteorology and photochemical air pollution in southern Europe: Experimental results from EC research projects, Atmos. Environ., 30, 1909-1924, 1996.

Millán, M., Salvador, R., Mantilla, E., and Kallos, G.: Photooxidant dynamics in the Mediterranean basin in summer: results from European research projects, J. Geophys. Res., 102, 88118823, 1997.

O'Neil, S. and Lamb, B.: Intercomparison of the Community Multiscale Air Quality Model and CALGRID using Process Analysis, Environ. Sci. Technol., 39, 5742-5753, 2005.

Ortega, S., Soler, M. R., Beneito, J., and Pino, D.: Evaluation of two ozone air quality modelling systems, Atmos. Chem. Phys., 4, 1389-1398, 2004, http://www.atmos-chem-phys.net/4/1389/2004/.

Parra, R., Gassó, S., an Baldasano, J. M.: Estimating the biogenic emissions of non-methane volatile organic compounds from the North western Mediterranean vegetation of Catalonia, Spain, Sci. Total Environ., 329, 241-259, 2004.

Parra, R., Jiménez, P., and Baldasano, J. M.: Development of the high spatial resolution EMICAT2000 emission model for air pollutants from the north-eastern Iberian Peninsula (Catalonia, Spain), Environ. Pollut., 140, 200-219, 2006.

Pérez, C., Sicard, M., Jorba, O., Comerón, A., and Baldasano, J. M.: Summertime re-circulations of air pollutants over the northeastern Iberian coast observed from systematic EARLINET lidar measurements in Barcelona, Atmos. Environ., 38, 3983-4000, 2004.

Roelofs, G. J., Scheeren, H. A., Heland, J., Ziereis, H., and Lelieveld, J.: A model study of ozone in the eastern Mediterranean free troposphere during MINOS (August 2001), Atmos. 
Chem. Phys., 3, 1199-1210, 2003,

http://www.atmos-chem-phys.net/3/1199/2003/.

San José, R., Pérez, J. L., Pleguezuelos, C., Camacho, F., and González, R. M.: MM5-CMAQ air quality modeling process analysis: Madrid case, Air pollution X, Ecology and the Environment vol. 53, ISBN:1-85312-916-X., C. A. BREBBIA, Wessex Institute of Technology, UK and University of the West of England, Bristol, UK, 2002.

Skamarock, W. C., Klemp, J. B., Dudhia, J., Gill, D. O., Barker, D. M., Wang, W., and Powers, J. G.: A Description of the Advanced Research WRF Version 2, NCAR Technical note NCAR/TN468+STR, NCAR, 2005.

Sillman, S. and He, D.: Some theoretical results concerning $\mathrm{O}_{3}$ $\mathrm{NO}_{\mathrm{x}}$-VOC chemistry and $\mathrm{NO}_{\mathrm{x}}-\mathrm{VOC}$ indicators, J. Geophys. Res., 107(D22), 4659, doi:10.1029/2001JD001123, 2002.

Soriano, C., Baldasano, J. M., Buttler, W. T., and Moore, K.: Circulatory Patterns of Air Pollutants within the Barcelona Air Basin in a Summertime situation: Lidar and Numerical Approaches, Bound.-Lay. Meteorol., 98(1), 33-55, 2001.

Taghavi, M., Cautenet, S., and Foret, G.: Simulation of ozone production in a complex circulation region using nested grids, Atmos. Chem. Phys., 4, 825-838, 2004, http://www.atmos-chem-phys.net/4/825/2004/.

Toll, I. and Baldasano, J. M.: Modeling of photochemical air pollution in the Barcelona area with highly disaggregated anthropogenic and biogenic emissions, Atmos. Environ., 34, 30603084, 2000.
US-EPA: Guideline for Regulatory Application of the Urban Airshed Model, US EPA Report No. EPA-450/4-91-013, Office of Air and Radiation, Office of Air Quality Planning and Standards, Technical Support Division, Research Triangle Park, North Carolina, USA, 1991.

US-EPA: Guidance on the Use of Models and Other Analyses for Demonstrating Attainment of Air Quality Goals for Ozone, $\mathrm{PM}_{2.5}$, and Regional Haze, EPA-454/B-07-002, US Environmental Protection Agency Office of Air Quality Planning and Standards Air Quality Analysis Division Air Quality Modeling Group Research Triangle Park, North Carolina, USA, April 2007, 262 pp., 2007.

Vautard, R., Bessagnet, B., Chin, M., and Menut, L.: On the contribution of natural Aeolian sources to particulate matter concentrations in Europe: Testing hypotheses with a modelling approach, Atmos. Environ. 39, 3291-3303, 2005.

Zhang, Y., Vijayaraghavan, K., Huang, J., and Jacobson, M. Z.: Probing into Regional $\mathrm{O}_{3}$ and PM Pollution: A 1-year CMAQ Simulation and Process Analysis over the United States, in: 14th Joint Conference on the Applications of Air Pollution Meteorology with the Air and Waste Management Association, 28 Janaury-2 February 2006, Atlanta, GA, USA, 2006. 